\title{
DISORDER IN THE COURT: THE DEATH PENALTY AND THE CONSTITUTION
}

\author{
Robert A. Burt*
}

The Supreme Court's decision in McCleskey v. Kemp ${ }^{1}$ marks the end of an era in the jurisprudence of the death penalty. In disregarding the petitioner's claim that he adequately had proven systemic race bias in the administration of capital punishment, the Court rejected the last generic challenge that had been on the agenda of the abolitionist attorneys from the outset of their litigative campaign in the early 1960s. ${ }^{2}$ After McCleskey, nothing appears left of the abolitionist campaign in the courts - nothing but the possibility of small-scale tinkering with the details of administration and, of course, persistent claims in lower courts of specific errors in the multitude of cases where the sentence is imposed.

For twenty years, the Court has struggled to determine the constitutional status of capital punishment. Broadly speaking, there have been three distinct phases in this effort: the first, beginning in 1968, when the Court announced substantial doubts about the constitutional validity of the death penalty; the second, beginning in 1976, when the Court attempted to appease those doubts by rationalizing and routinizing the administration of the penalty; and the third, beginning in 1983 and culminating this Term in McCleskey, when the Court proclaimed the end of its doubts and correspondingly signalled its intention to turn away from any continuing scrutiny of the enterprise. Each of these pronouncements was accompanied by sharp divisions within the Court. No firm resolution of underlying issues ever took hold, moreover, because the dissenters in each phase were never reconciled to their minority status. Each defeat was read by the dissenters as merely an occasion for biding time until Court personnel might change or some member of the current Court majority might be pried loose to form a new, inconsistent majority. Stare decisis has never

* Southmayd Professor of Law, Yale University. A.B. 1960, Princeton University; M.A. 1962, Oxford University; J.D. 1964, Yale Law School. - Ed. I have gotten invaluable assistance in writing this article from Akhil Amar, Arthur England, Abe Goldstein, Joe Goldstein, Owen Fiss, Rick Lempert, Jay Pottenger, Dan Rabinowitz, and Ron Wright.

1. 107 S. Ct. 1756 (1987).

2. See M. Meltsner, Cruel and Unusual: The Supreme Court and Capital PunISHMENT 73-78 (1973). 
been a preeminent value in constitutional adjudication; ${ }^{3}$ but judicial disrespect for this value has been especially pronounced in the course of the Court's consideration of capital punishment issues. Each phase of the Court's work apparently has been viewed by the Justices not as an end to the battle, hardly even as a formal truce, but more as a momentary pause in the pursuit of irreconcilable hostilities. ${ }^{4}$

In an ironically revealing way, the unremitting internal conflict that has characterized the Court's death penalty adjudication mirrors concerns about polarized hostility in American society generally. These concerns arise from two related questions about our society: whether relentless racial and class conflict precludes the possibility of any strong communal bonds, and, in any event, whether individual competitive antagonism is so prevalent as to undermine the force of any binding group loyalties.

Large jurisprudential issues hang on the answers to these questions. If American society is a place of deeply polarized conflict, then the rule of law is endangered whether that rule is minimally conceived as the preservation of social order or ideally envisioned as the expression of shared commitment to fundamental principles of justice. Differing conceptions of the proper judicial role in vindicating the rule of law also depend on the answers to these questions. If implacable hostilities run deep in our society, then judicial deference to legislative action appears to invite majority oppression of minorities; yet active judicial protection of threatened minorities would appear to provoke escalated, retaliatory strikes by the majority against both the minorities and their judicial allies. The belief that our society is gripped by barely constrained, relentless warfare thus raises the stakes on all sides of the jurisprudential debate about the proper role of constitutional adjudication in defining and protecting the rule of law.

This question about the character of social conflict in America has been an underlying theme of the Supreme Court's work on the death penalty. In the course of this work over the past twenty years, a discernible change has appeared in the Justices' answers to this question. In 1968, a majority of the Justices still held to the belief, which had

3. See Maltz, Some Thoughts on the Death of Stare Decisis in Constitutional Law, 1980 WIS. L. REv. 467.

4. This characteristic is not restricted to the Court's death penalty work. Cf. Garcia v. San Antonio Metro. Transit Auth., 469 U.S. 528, 580 (1985) (Rehnquist, J., dissenting) (“[This] principle ... will, I am confident, in time again command the support of a majority of this Court."); 469 U.S. at 589 (O'Connor, J., dissenting) ("I share Justice Rehnquist's belief that this Court will in time again assume its constitutional responsibility."). The practice of relentless dissent is a relatively recent phenomenon in Supreme Court jurisprudence. See Kelman, The Forked Path of Dissent, 1985 SUP. CT. REV. 227. 
been dominant throughout the tenure of the Warren Court, that our social conflicts were potentially reconcilable because we were fundamentally a united people. Even Justices Brennan and Marshall, the surviving remnant of that majority, have apparently abandoned this belief; the dominant - perhaps even the unanimous - view on the current Court is that America is fundamentally characterized by irreconcilable conflict.

This article has two purposes. Its first aim is to trace the significance of these shifting characterizations of American society in the Justices' successive approaches to the death penalty by retelling the story of the Court's capital punishment jurisprudence. Its second purpose is to suggest that belief in implacable social hostility destroys the coherence of the judicial role in constitutional adjudication. America may indeed be an irreconcilably polarized society; I cannot dispositively prove or disprove the proposition. I mean only to claim that in constitutional adjudication a judge is obliged to act as if this proposition were false; and, moreover, the judge must try to demonstrate its falsity in the very process of constitutional adjudication. I intend to pursue this second purpose in this article by direct argumentation, but even more by force of the example provided by the course and the failures of the Court's capital punishment jurisprudence.

\section{Phase I: Doubts Emergent}

The origins of the Court's death penalty reform efforts can be traced to 1932, when it ruled that state criminal defendants have a right to appointed attorneys in capital cases. ${ }^{5}$ This was a striking innovation not only in its own terms but also in the willingness of the Court to use the generalities of the fourteenth amendment to effect any systemic change in state criminal justice systems. Until 1963, the Court restricted application of this rule to capital cases, requiring a showing of "special circumstances" to apply the right in other cases. ${ }^{6}$ The death penalty was thus denoted an inevitably "special circumstance" in constitutional jurisprudence.

During all this time, the Court invariably treated death cases with special care - sometimes using them as occasions for significant constitutional law innovations, ${ }^{7}$ sometimes obviously (but tacitly) stretch-

5. Powell v. Alabama, 287 U.S. 45 (1932).

6. See Betts v. Brady, 316 U.S. 455 (1942), overruled by Gideon v. Wainwright, 372 U.S. 335 (1963).

7. See, e.g., Powell v. Alabama, 287 U.S. 45 (1932) (establishing right to appointed counsel); Avery v. Georgia, 345 U.S. 559 (1953) (prohibiting racial discrimination in the composition of juries); Fikes v. Alabama, 352 U.S. 191 (1957) (establishing inadmissability of involuntary confessions). 
ing received doctrine out of shape to overturn a particular death sentence. ${ }^{8}$ The Court's persistent special attention to death sentences showed some measure of constitutional pressure to tame and to regularize the application of the penalty but it was only indirect, atmospheric. To adapt Dr. Johnson's formulation, the prospect of the petitioner's death seemed wonderfully to concentrate the Justices' minds.

It seemed unlikely, however, during this early time - this prehistory of death penalty jurisprudence - that a constitutional claim against the death penalty as such would ever gain serious attention. The very text of the Constitution seemed to conclude the matter with the fifth amendment's explicit, though backhanded, endorsement that a person might be "deprived of life" so long as "due process of law" was observed. 9 As late as 1958, Chief Justice Warren - a jurist not usually noted for resistance to constitutional innovation - testified to the implausibility of any constitutional claim against the death penalty:

Whatever the arguments may be against capital punishment, both on moral grounds and in terms of accomplishing the purposes of punishment - and they are forceful - the death penalty has been employed throughout our history, and, in a day when it is still widely accepted, it cannot be said to violate the constitutional concept of cruelty. ${ }^{10}$

Barely five years later, however, the first evidence that the Justices might consider a constitutional challenge to the penalty as such appeared in the pages of the United States Reports. In a dissent from a denial of certiorari, Justice Goldberg (joined by Justices Douglas and Brennan) argued that the Court should have taken the case to consider whether the death penalty could properly be imposed for rape where the victim's life had neither been taken nor seriously threatened."1 The case came from Alabama, the defendant was black, his victim was white; but Justice Goldberg did not mention race in his opinion, speaking only of the possibility that death was a disproportionate, and thus "cruel and unusual," punishment for rape.12

Goldberg's dissent provided the barest public hint of a private discussion that he had initiated within the Court. Before preparing his

8. E.g., Stein v. New York, 346 U.S. 156, 196 (1953) ("When the penalty is death, we, like state court judges, are tempted to strain the evidence and even, in close cases, the law in order to give a doubtfully condemned man another chance."). See also B. PRETTYMAN, DeATH AND THE SUPREME COURT 41-42, 287, 298 (1961).

9. U.S. CONST. amend. V ("No person shall . . . be deprived of life, liberty or property, without due process of law. ...").

10. Trop v. Dulles, 356 U.S. 86, 99 (1958) (Warren, C.J., plurality opinion).

11. Rudolph v. Alabama, 375 U.S. 889 (1963) (Goldberg, J., dissenting).

12. See M. MELTSNER, supra note 2, at 28-29. 
dissent, Goldberg had circulated a memorandum to his brethren expressing his judgment that the death penalty, not only as imposed for rape but generally, violated the eighth amendment. In 1986, Goldberg published the full text of this memorandum; ${ }^{13}$ and in his 1986 Holmes Lecture at the Harvard Law School, Justice Brennan observed that Goldberg's memorandum had been "highly unusual for several reasons."

First, although not unheard of, it was (and still is) most unusual for an individual Justice to take it upon himself or herself to write at length, prior to our conference, about cases which had neither been argued nor even set for argument, and then to circulate that memorandum to all of his or her colleagues. Second, ... the constitutionality of the death penalty ... had received relatively little attention from the courts and ... was not, at that time, an issue upon which either litigants or the press had begun to focus. ... [I]n not one of the six [pending capital] cases had any party directly challenged ... the validity of capital punishment under the eighth amendment. ${ }^{14}$

Justice Goldberg acknowledged the novelty of his position at the end of his memorandum - "I recognize that my Brethren may not agree with . . . my view" - and urged the Court to consider the validity of capital punishment "at least for certain types of crimes and on certain types of offenders."1s Goldberg could not attract three other votes for certiorari on this basis, and his public dissent followed. Nonetheless, a conversation had been launched within the Court.

In 1968, just five years after this initial stirring, a Court majority publicly acknowledged substantial doubts about the constitutional status of capital punishment. By then, the NAACP Legal Defense Fund, partly prompted by Justice Goldberg's 1963 dissent, had launched a national litigative campaign against the constitutionality of the death penalty. ${ }^{16}$ In 1967, the Court had unanimously directed the Eighth Circuit Court of Appeals to hear an allegation of race discrimination by a black man sentenced to death for raping a white woman. ${ }^{17}$ But the Fund's litigative campaign was not restricted to the race issue, ${ }^{18}$ and by 1968 Fund attorneys and others loosely allied with them had

13. Goldberg, Memorandum to the Conference Re: Capital Punishment, October Term, 1963, 27 S. TEX. L.J. 493 (1986).

14. Brennan, Constitutional Adjudication and the Death Penalty: $A$ View from the Court, 100 HARV. L. REV. 313, 314-15 (1986).

15. Goldberg, supra note 13 , at 504.

16. See M. MELTSNER, supra note 2, at 30-35, 73-105. For a perceptive critical account of this launching, see Muller, The Legal Defense Fund's Capital Punishment Campaign: The Distorting Influence of Death, 4 YALE L. \& POLY. REV. 158 (1985).

17. Maxwell v. Bishop, 385 U.S. 650 (1967).

18. See M. MELTSNER, supra note 2, at 106. For an evaluation of the Fund's decision to broaden its litigative concerns beyond race issues, see Muller, supra note 16, at 169-70, 180-87. 
obtained judicial orders throughout the country that amounted to a national moratorium against executions while various novel constitutional claims were being pursued. ${ }^{19}$ When the Supreme Court decided Witherspoon v. Illinois ${ }^{20}$ in 1968 , no one had been executed in the United States for more than a year. ${ }^{21}$

Witherspoon involved state efforts to avert jury nullification in death penalty cases. Concern about nullification lay behind the legislative enactments in the nineteenth century which transformed the death penalty from a mandatory sentence in virtually all felonies to a discretionary sentence in a restricted list of felonies. ${ }^{22}$ The draconian appearance of the mandatory regime had been belied by a widely acknowledged refusal by juries to apply the laws as written. Late nineteenth-century legislatures did not try to override this jury lawlessness but accommodated it by formally legitimizing jury discretion. ${ }^{23}$ In Witherspoon the Supreme Court took a similar tack.

The issue addressed in Witherspoon was the proper standard for excluding potentially nullifying jurors from capital cases. An Illinois statute provided that a juror might be excluded if, "on being examined, [he] state[s] that he has conscientious scruples against capital punishment."24 The Court found this standard too lax. It held that while the state might legitimately exclude prospective jurors who would "invariably" or "automatically" vote against the death penalty, it could not exclude those who simply "voiced general objections to the death penalty or expressed conscientious or religious scruples against its infliction."25

Witherspoon addressed only the administration of the death penalty and, in this sense, might have seemed implicitly to affirm the constitutional validity of the penalty. But doubts about the propriety of the penalty nonetheless appeared in the Court's opinion, written by Justice Stewart:

[A] jury that must choose between life imprisonment and capital punishment can do little more - and must do nothing less - than express the conscience of the community on the ultimate question of life or death. Yet, in a nation less than half of whose people believe in the death penalty, a jury composed exclusively of such [believers] cannot speak for the

19. See M. MeltsNer, supra note 2, at 107-09, 126-48.

20. 391 U.S. 510 (1968).

21. See M. MeLTSNer, supra note 2, at 113.

22. See H. Bedau, The Death Penalty in America 27 (2d ed. 1968).

23. Knowlton, Problems of Jury Discretion in Capital Cases, 101 U. PA. L. Rev. 1099, 1102 \& n. 18 (1953).

24. 391 U.S. at 512.

25. 391 U.S. at 522. 
community. Culled of all who harbor doubts about the wisdom of capital punishment - of all who would be reluctant to pronounce the extreme penalty - such a jury can speak only for a distinct and dwindling minority. ${ }^{26}$

Three extraordinary footnotes punctuated this passage. The footnote to the second sentence cited opinion polls indicating not only a close division between supporters and opponents of capital punishment (the tally was $42 \%$ favoring, $47 \%$ opposed, and $11 \%$ undecided in 1966), but also an erosion of support since 1960 (when the count had been $51 \%$ favoring, $36 \%$ opposed, and $13 \%$ undecided). ${ }^{27}$ In the next sentence, after characterizing death penalty supporters as a "distinct and dwindling minority," the Court added a footnote that seemed to endorse a pejorative vision of these supporters. With the injunction "compare," the Court quoted this passage from Arthur Koestler's book, Reflections on Hanging:

The division [between supporters and opponents of hanging] is not between rich and poor, highbrow and lowbrow, Christians and atheists: it is between those who have charity and those who have not.... The test of one's humanity is whether one is able to accept this fact - not as lip service, but with the shuddering recognition of a kinship: here but for the grace of God, drop I. $^{28}$

These observations were not presented as the preface to a judicial conclusion that the death penalty was unconstitutionally cruel and unusual punishment. They might have served this function; in the footnote that immediately preceded these two, the Court cited the ideals of "decency" and "progress" invoked by Chief Justice Warren in his 1958 opinion as a touchstone for applying the eighth amendment guarantee - "the evolving standards of decency that mark the progress of a maturing society." 29 This citation was not, however, an indication that the Court itself was prepared to recognize an evolution — to read Koestler's words and the polling data and to conclude that the death penalty had come to violate the constitutional norm. The Court cited Warren's standard in this context:

[O]ne of the most important functions any jury can perform . . . is to maintain a link between contemporary community values and the penal system - a link without which the determination of punishment could hardly reflect "the evolving standards of decency that mark the progress

26. 391 U.S. at $519-20$ (footnotes omitted).

27. 391 U.S. at 520 n.16.

28. 391 U.S. at 520 n.17 (quoting A. Koestler, Reflections ON HANGING 166-67 (1956)).

29. 391 U.S. at 519 n.15 (citing Trop v. Dulles, 356 U.S. 86, 101 (1958) (Warren, C.J., plurality opinion)). 
of a maturing society."30

These three footnotes, taken together, suggest that the Court had concluded that even though state legislatures had approved capital punishment, there were substantial reasons to doubt its propriety and conscionability; and further that if judges might not (or might not yet) properly find in these doubts a basis for questioning the constitutionality of the death penalty, juries in individual cases could be the proper institution for this purpose. Yet the Court only toyed with this idea, hinted at it, but stopped short of embracing it.

The explicit stopping point came with the Court's willingness to permit exclusion of jurors who were "invariably"31 or "automatically" 32 opposed to imposing the death penalty. At this point, a positivist premise reasserted itself: the jury as the obedient instrument of the legislative will. In yet another footnote, the Court invoked this positivism:

It is entirely possible, of course, that even a juror who believes that capital punishment should never be inflicted and who is irrevocably committed to its abolition could nonetheless subordinate his personal views to what he perceived to be his duty to abide by his oath as a juror and to obey the law of the State. ${ }^{33}$

The Court walked a narrow line in all of this. That narrowness was revealed by the individual opinions written by Justices on its right and its left. On one side, Justice White argued in dissent that the state was entitled to select jurors who would enthusiastically implement its chosen policy. Whatever doubts existed about the propriety of capital punishment, White suggested, were only properly addressed in legislatures, and the majority might choose to exclude the defeated minority from the administration of the policy opposed by it. ${ }^{34}$ (White indeed chided the Court for its own apparent "strong dislike" for capital punishment and its seeming "desire to meet Mr. Koestler's standards of charity.") $)^{35}$ White's is an unencumbered positivism, unlike the Court's garbled version.

On the other side, Justice Douglas argued in a separate opinion that opposition to capital punishment, no matter how adamant, was an impermissible basis for any juror's exclusion. ${ }^{36}$ Douglas based this view on the proposition that "a jury [must] be drawn from a cross-

\footnotetext{
30. 391 U.S. at 519 n.15.

31. 391 U.S. at 515.

32. 391 U.S. at 522 n.21 (emphasis omitted).

33. 391 U.S. at $514-15$ n.7.

34. 391 U.S. at $541-42$ (White, J., dissenting).

35. 391 U.S. at 542.

36. 391 U.S. at 528 (Douglas, J., separate opinion).
} 
section of the community."37 Accordingly, it would seem, each jury must be constituted as if it were a mini-legislature with at least implicit authority to reopen the question of penal policy that its larger counterpart, the [maxi-]legislature, had previously resolved.

Douglas' opinion embraced the possibility - if not openly espoused the propriety - of jury nullification; White's dissent emphatically rejected nullification in practice and principle. The Court majority weaved and bobbed. Even the way the Court invoked the juror's "oath" of obedience conveyed its ambivalence: "a juror . . . could nonetheless subordinate his personal views to what he perceived to be his duty to abide by his oath . . . and to obey the law of the State."38 Omit the italicized words and we are flatly in the positivist universe. Include them and we have a conception of the jury not as Douglas would have it, not as a "mini-legislature," but almost as a miniature article III court.

Under this latter construction, each juror, like a federal judge, is obliged to "subordinate his personal views" to the positive law, but is permitted to make an independent evaluation of that law. A juror is obliged, like a federal judge, to give deference to state law but not to obey it slavishly. I would take the image even a step further: as the Court invited the juror to consult his conscience, to obey his duty as he perceived it, the Court implicitly invoked an analogy not simply with article III courts generally but specifically with one such Court - the Warren Court.

Witherspoon was one of the last acts of the Warren Court. The decision came on June 3, 1968, at the end of the last full Term in which Chief Justice Warren sat (as well as the last full Term of Justice Fortas, his first-nominated successor). It was, moreover, a characteristic work product of that Court in many ways. In its boldly stated normative vision and redolent high idealism coupled with a modest enforcement regime of uncertain efficacy, Witherspoon was vintage Warren Court - comparable to Brown v. Board of Education ${ }^{39}$ and segregation ended with "all deliberate speed,"40 or Miranda v. Arizona ${ }^{41}$ and its right not to appointed counsel but to a police warning that offered counsel. In Witherspoon, the Court seemed to suggest that in a humane regime the death penalty would have no place, and to predict that truly representative jurors would implement this moral

37. 391 U.S. at 532.

38. 391 U.S. at 514-15 n.7 (emphasis added).

39. 347 U.S. 483 (1954).

40. Brown v. Board of Educ., 347 U.S. 294, 301 (1955) (Brown II).

41. 384 U.S. 436 (1966). 
vision; but the Court's specific holding left room, perhaps ample, for excluding jurors opposed to capital punishment. Thus, as in the other landmarks of the Warren era, the Court thundered, but the precise import of its decision - even whether the decision would change anything of practical significance ${ }^{42}$ - remained obscure, dependent on subsequent developments and future implementation by lower courts and by the Justices themselves.

Witherspoon can be read as a public expression of the same strategy that Justice Goldberg had pursued in 1963 in the privacy of the Court's deliberations. ${ }^{43}$ That is, the Court majority, though doubting the validity of capital punishment, was nonetheless aware that others might not share those doubts or might not yet have seriously engaged the issue; and accordingly, the majority, like Goldberg to his brethren, tried to launch a public deliberation. Witherspoon was also vintage Warren Court in this sense: the decision hinted at the Court's own predilection without definitively resolving an issue, thereby unsettling long-standing practices, seizing public attention, and provoking public dispute.

Witherspoon was a characteristic Warren Court work product in an even more fundamental way. The decision visibly reflected that Court's customary confidence in the fundamental stability, even harmony, of American society. The Court in Witherspoon thus did not invite jury nullification - lawless conduct - but it indicated tolerance for this possibility and confidence that nullification would remain confined within limits that adequately accommodated the maintenance of social order. This was also the Warren Court's attitude toward its own judicial role as nullifier of majoritarian actions - that its preference for minority rights was not inconsistent with a regime of social order, that its nullifications would ultimately establish a more stable, ordered regime than if it invariably displayed or commanded reflexive deference to majority will.

Witherspoon was the first but not the last Supreme Court decision to raise the possibility that the death penalty as such might be unconstitutional. The latter distinction was earned by the Court's 1972 decision in Furman v. Georgia ${ }^{44}$ where five Justices found the death

42. So Justice Black suggested in his dissent in Witherspoon: "[T]he real holding in this case is, at least to me, very ambiguous. If we are to take the opinion literally, then I submit the Court today has decided nothing of substance, but has merely indulged itself in a semantic exercise." 391 U.S. at 538 (emphasis in original). By contrast, however, "[i]nitially, Witherspoon gave abolitionist lawyers cause to believe that no one would ever be executed again." M. MELTSNER, supra note 2 , at 123 .

43. See text at note 13 supra.

44. 408 U.S. 238 (1972). 
penalty to be cruel and unusual punishment. Though their reasons for this conclusion differed, the combined import of the Justices' opinions seemed at the time to bar any practicably imaginable future death penalty legislation. ${ }^{45}$ As it turned out, Furman was short-lived; four years later the Court effectively reversed direction. ${ }^{46}$

Furman has persisting significance, however, in one fundamental way; and in that way it has less in common with Witherspoon than it has with the subsequent Supreme Court decisions which validate the death penalty. Witherspoon testified to the Warren Court's faith that responsible deliberative processes might occur not only in jury rooms but in public forums generally and, accordingly, that the Court might exercise persuasive rather than peremptory authority. The Court believed that it might profitably engage in a deliberative exchange with elected officials and the public at large rather than simply issue commandments. Furman revealed that this faith had passed with the end of the Warren Court.

The moment of passage was illuminated by a decision that intervened between Witherspoon and Furman. In McGautha v. California, ${ }^{47}$ decided in 1971, Justice Harlan was spokesman for the Court. Harlan not only had dissented in Witherspoon but had been the most consistent and adamant opponent of the Warren Court's optimistic liberalism. ${ }^{48}$ Harlan was never strident in stating his preference for communal over individual claims, for Order over Justice. He persistently avowed, however, that choice between these antinomies was inevitable, that they could not be harmonized and perhaps not even tolerably accommodated through a process of public deliberation; and he consistently held to a patrician vision commanding fealty to the existing communal order. ${ }^{49}$

The issues raised in McGautha were whether state law must prescribe specific substantive standards to govern jury discretion in imposing a death sentence and whether a bifurcated trial was required to separate both the evidence presented and jury deliberations regarding

45. For example, see the optimistic reading in 1973 of Furman's implications by a Legal Defense Fund attorney in M. MELTSNER, supra note 2, at 289, 309-16.

46. Gregg v. Georgia, 428 U.S. 153 (1976).

47. 402 U.S. 183 (1971).

48. See D. O'Brien, Storm Center: The Supreme Court in American Politics 272 (1986).

49. See Bourguignon, The Second Mr. Justice Harlan: His Principles of Judicial Decision Making, 1979 SuP. Cr. REv. 251; Weisberg, Deregulating Death, 1983 SuP. CT. REv. 305, 31011 (characterizing Harlan as a Burkean "skeptic" who believed that "life generally is unfair, and the law need be no fairer"); Brennan, supra note 14, at 319 (noting "a certain lofty conservatism" in Harlan's jurisprudence "premised on ... a conviction that there are limits to what heights we should reasonably expect people and society to ascend"). 
guilt and punishment. The Court held that neither substantive standards $^{50}$ nor procedural bifurcation ${ }^{51}$ were constitutionally required. This decision was not logically inconsistent with Witherspoon; the question of jury composition is distinct from questions about the nature and presentation of the task entrusted to it. Witherspoon and $M C$ Gautha nonetheless faced dramatically different directions: the former appeared intent on harnessing the jury toward ameliorating, if not ultimately abolishing, the application of the death penalty while the latter seemed wholly agnostic in this regard.

For Harlan, in his opinion for the Court, this agnosticism followed from the basic attitude that had marked his persistent dissents in the Warren era. He revealed this attitude most clearly in his rationale for refusing to require the specification of substantive standards for death sentences. He reasoned, "The infinite variety of cases and facets to each case would make general standards either meaningless "boilerplate' or a statement of the obvious that no jury would need."s2 For this reason, Harlan concluded, "To identify before the fact those characteristics of criminal homicides and their perpetrators which call for the death penalty, and to express these characteristics in language which can be fairly understood and applied by the sentencing authority, appear to be tasks which are beyond present human ability."53 The underlying premise in this reasoning is that each jury, in deciding whether or not to impose a death penalty, inevitably constitutes a "law unto itself": it acts without necessary connection to the community from which it is drawn.

Justice Brennan dissented in McGautha, and he drew out the stark implications of Harlan's underlying premise. This was, he said, "an unguided, unbridled, unreviewable exercise of naked power."54 Jury discretion may be appropriate in death sentencing, Brennan asserted:

But discretion, to be worthy of the name, is not unchanneled judgment; it is judgment guided by reason and kept within bounds. Otherwise, in Lord Camden's words, it is "the law of tyrants: It is always unknown: It is different in different men: It is casual, and depends upon constitution, temper, passion. - In the best it is oftentimes caprice: In the worst it is every vice, folly, and passion, to which human nature is liable." 55

To this stark juxtaposition of the unchanneled "law of tyrants" and

50. 402 U.S. at 207.

51. 402 U.S. at 213 .

52. 402 U.S. at 208.

53. 402 U.S. at 204.

54. 402 U.S. at 252 (Brennan, J., dissenting).

55. 402 U.S. at 285 (quoting Hindson \& Kersey, cited in 8 State Tr. (Howell) 57 n.). 
the bounded "rule of law," Brennan added a clinching argument, as he saw it: the state had not tried to devise standards and the Court was refusing to require even that the effort be made. "We are not presented with the slightest attempt," he said, "to bring the power of reason to bear on the considerations relevant to capital sentencing." 56

If it were true, Brennan observed, that this attempt was clearly preordained to fail, then he would draw a different conclusion: "[E]ven if I shared the Court's view that the rule of law and the power of the States to kill are in irreconcilable conflict, I would have no hesitation in concluding that the rule of law must prevail." 57 If the death penalty and the rule of law were irreconcilable, the death penalty would be unconstitutional. But, Brennan concluded, no clearly demonstrated "irreconcilable conflict" existed here; none could until (as yet untried) state efforts to devise standards had failed.

In this dissent, Justice Brennan still spoke in the quintessential voice of the Warren Court: his paean to the rule of the law and its equivalence to a judicialized model of reasoned, "standards-bounded" deliberation applicable to all governmental actions, and his commitment to an incremental process of case-by-case constitutional adjudication by which this value might be realized or its attainability tested. His disagreement with Justice Harlan was the same debate that had occurred during the Warren years, except that Harlan now spoke for the Court majority. In their contrasting attitudes toward the role of the jury, the basic elements of this long-standing disagreement were apparent.

The jury, as Harlan portrayed it in McGautha, was the embodiment of the individual isolated from the community. The effort to devise legislative standards, which Harlan eschewed in McGautha, would have been an attempt to counteract this isolation, to assure some strong connection between jury and community - an assurance that Witherspoon demanded (over Harlan's dissent) regarding jury composition. For Harlan, this isolation is "intractable" - not to be judicially opposed, hardly even to be regretted, but a simple fact of social life.

If the jury and community could not be connected reliably except by whatever representation might be achieved through the randomness of the jury selection process, what then would assure a just result in the imposition of death sentences? This was Brennan's challenge, and Harlan answered it in a way that revealed his belief in the inevita-

56. 402 U.S. at 252.

57. 402 U.S. at 249-50. 
ble disjunction between Order and Justice. "The States are entitled to assume," Harlan said, "that jurors confronted with the truly awesome responsibility of decreeing death for a fellow human will act with due regard for the consequences of their decision. ..."58 Harlan invoked a concentric series of assumptions here: courts assume that states assume that juries will act with "due regard" for Justice. For all that the Court knew in McGautha, the states in fact assumed and were happy that juries will "decide on whimsy or caprice" to impose death; but states, Harlan said, "are entitled to assume" otherwise, and the Court will ask no questions about either the existence or the plausibility of this assumption.

Only by this adamant refusal to ask questions was Harlan able to square the circle and ostensibly harmonize the demands of Order (imposed by the most extreme sanction) with norms of Justice. Harlan was not prepared to follow the logic of Brennan's position in $M C$ Gautha that if imposition of the death penalty and the rule of law were irreconcilable, then Justice should prevail. By Harlan's lights, there was an irreconcilable conflict and Order must not be sacrificed.

Soon thereafter, Brennan came to share Harlan's initial premise in McGautha. Brennan concluded, as had Harlan, that Justice and Order could not be reconciled in the administration of the death penalty - "that the rule of law and the power of the States to kill are in irreconcilable conflict," as he had put it in his McGautha dissent. ${ }^{59}$ As he had rhetorically envisioned in McGautha, this conclusion led Brennan to a different ultimate result from Harlan's, finding death an impermissible penalty as such, preferring Justice to Order since these two values now appeared irreconcilable. This was the result Brennan reached in Furman v. Georgia, ${ }^{60}$ just one year after McGautha. By then, Harlan was gone from the Court; McGautha had been one of his last published opinions. ${ }^{61}$ And Brennan was with the majority in Furman that voted, though for different reasons, to overturn the death penalty.

Of the Justices who participated in both McGautha and Furman, four (including Brennan) took apparently inconsistent positions in the two cases. Justice Marshall had concurred in Brennan's McGautha dissent and in Furman he concluded with Brennan that the death pen-

58. 402 U.S. at 207-08.

59. 402 U.S. at 249-50 (Brennan, J., dissenting).

60. 408 U.S. 238, 257 (1972) (Brennan, J., concurring).

61. Justice Harlan resigned from the Court on September 23, 1971; McGautha was decided on May 3, 1971. 
alty as such was unconstitutional.62 Justices Stewart and White had joined the McGautha majority, but in Furman they voted to invalidate the death penalty apparently because of the absence of discernible rational criteria in its application ${ }^{63}$ - a standard that McGautha had pointedly rejected. Only Justice Douglas seemed to hold consistently to the same position in the two cases (though his exact position is difficult to grasp, since he wrote in Furman with his customary, carelessly obscure style). ${ }^{64}$

Of all these shifts between McGautha and Furman, Brennan's is easiest to trace because he alone wrote in both cases. And Brennan's shift most noticeably raised troubling problems for the goal he sought in both cases, to vindicate "the rule of the law" in the administration of the death penalty. Brennan's shift might be explained by a narrow distinction available between the two cases - that the Court had specifically restricted the grant of certiorari in McGautha to a "due process" challenge ${ }^{65}$ and in Furman the logically distinct "cruel and unusual punishment" issue was addressed. ${ }^{66}$ But this is a logic-chopping distinction. If Brennan's dissenting views had been the majority position in McGautha, the Court would have effectively invalidated all extant death penalty statutes and launched a process in which any reenactments would be measured against various norms of rationality in their overall conception and specific administration (such as proportionality of crime and punishment, comprehensiveness of the considerations arrayed, clarity of the enunciated standards, and consequent predictability in application). It is most improbable that barely a year after this process had been launched, the Court would have been prepared to declare it a misadventure by invalidating the penalty as such under the eighth amendment, or if not improbable at least unexpected, abrupt, erratic - in a word, injudicious. These are the adjectives called to mind by Justice Brennan's quick change between McGautha and Furman, though he spoke for himself alone and not for the Court in either instance.

There was another more patently troubling sense in which Justice Brennan's position in Furman strained ordinary norms of judicial conduct, implicitly undermining his effort to vindicate the rule of law.

62. 408 U.S. at 370-71 (Marshall, J., concurring).

63. 408 U.S. at 309-10 (Stewart, J., concurring); 408 U.S. at 313 (White, J., concurring).

64. 408 U.S. at $248 \mathrm{n} .11$ (Douglas, J., concurring) ("The tension between our decision today and McGautha highlights, in my view, the correctness of Mr. Justice Brennan's dissent in that case, which I joined.").

65. 398 U.S. 936 (1970).

66. 408 U.S. at 239. 
Brennan's conclusion that the death penalty violated the eighth amendment stricture against "cruel and unusual punishment" hung on a scaffolding of reasons that seemed jerrybuilt for the occasion. Only three Supreme Court cases before Furman had relied on the eighth amendment to invalidate any punishments at all (in 1910,67 1958,68 and $1962^{69}$ ), none of which involved the death penalty; and only three Supreme Court cases had directly considered eighth amendment challenges to the death penalty, upholding death in 1879 by shooting, ${ }^{70}$ in 1890 by electrocution, ${ }^{71}$ and in 1947 by repeated application when the first attempt to electrocute had failed. ${ }^{72}$

From this skimpy material, Justice Brennan erected a complex argument adducing four "interrelated" and "ordinarily . . . cumulative"73 principles to support his conclusion that the death penalty, in the statutes of the United States and forty states, violated the eighth amendment. ${ }^{74}$ Unlike most other intellectual endeavors, obvious originality is not a prize-winning category for judicial opinions. There is, in this sense too, an unexpected and therefore apparently injudicious aspect to Brennan's effort in Furman.

Justice Blackmun's dissent in Furman was particularly critical of Brennan and the other members of the majority on this score: "The Court has recognized, and I certainly subscribe to the proposition, that the Cruel and Unusual Punishments Clause 'may acquire meaning as public opinion becomes enlightened by a humane justice.' . . . My problem, however, ... is the suddenness of the Court's perception of progress in the human attitude...."75 Two of the other dissenters sounded this same note: Chief Justice Burger spoke of "instant evolution in the law,"76 while Justice Powell characterized Brennan's position as "precipitate." 77 But Blackmun's critique carried an added force because his opinion so clearly, and even poignantly, revealed how much he would have liked to concur with Brennan. Blackmun

67. Weems v. United States, 217 U.S. 349 (1910).

68. Trop v. Dulles, 356 U.S. 86 (1958).

69. Robinson v. California, 370 U.S. 660 (1962).

70. Wilkerson v. Utah, 99 U.S. 130 (1879).

71. In re Kemmler, 136 U.S. 436 (1890).

72. Louisiana ex. rel. Francis v. Resweber, 329 U.S. 459 (1947).

73. Furman v. Georgia, 408 U.S. 238, 282 (1972) (Brennan, J., concurring).

74. 408 U.S. at 305.

75. 408 U.S. at 409-10 (Blackmun, J., dissenting) (quoting Weems v. United States, 217 U.S. $349,378(1910))$.

76. 408 U.S. at 382 (Burger, C.J., dissenting).

77. 408 U.S. at 430 (Powell, J., dissenting). 
began his dissenting opinion with, as he said, these "somewhat personal" comments:

Cases such as these provide for me an excruciating agony of the spirit. I yield to no one in the depth of my distaste, antipathy, and, indeed, abhorrence, for the death penalty, with all its aspects of physical distress and fear and of moral judgment exercised by finite minds. That distaste is buttressed by a belief that capital punishment serves no useful purpose that can be demonstrated. For me, it violates childhood's training and life's experiences, and is not compatible with the philosophical convictions I have been able to develop. It is antagonistic to any sense of "reverence for life."78

In this brief statement, Blackmun recited almost a catechism of the four-part test that Brennan distilled for the application of the eighth amendment: whether a punishment is "degrading to human dignity," inflicted in "arbitrary fashion," decisively "rejected throughout society," and "patently unnecessary."79 But for Blackmun these principles had no constitutional status; they were a basis for "legislative" actions, not "judicial" pronouncements abolishing the death penalty. ${ }^{80}$

It is commonplace in a dissenting judicial opinion to charge that the majority has ignored canons of judicial restraint and wrongly relied on "personal" or "policy" views to invalidate legislation. All of the dissenters in Furman invoked this formulation;81 Justice Rehnquist, indeed, said nothing more than this. ${ }^{82}$ Blackmun's invocation had, however, a special tone: an absence of rhetorical flourish, an obvious struggle between his conscience and his conception of judicial role obligations, that marks it apart not only from the other dissenters in Furman but from other expressions of this dissenting tradition. Unlike Justice Frankfurter, for example - who had been the most practiced opinion-writer in this genre ${ }^{83}$ - Blackmun did not reiterate this charge as a dogma for all seasons, a hairshirt worn to prove a suitably judicial temperament. Blackmun's opinion for the Court the year after Furman, in Roe v. Wade, ${ }^{84}$ showed his flexibility on this score, his willingness to consider novel constitutional interpretations to invalidate well-entrenched legislation. Blackmun's heartfelt dissent in Furman thus raised an unusually pointed question about the inability

78. 408 U.S. at $405-06$.

79. 408 U.S. at 281 (Brennan, J., concurring).

80. 408 U.S. at 411.

81. 408 U.S. at 375-76 (Burger, C.J., dissenting); 408 U.S. at 411 (Blackmun, J., dissenting); 408 U.S. at 418 (Powell, J., dissenting).

82. 408 U.S. at 465-70 (Rehnquist, J., dissenting).

83. See, e.g., Trop v. Dulles, 356 U.S. 86, 128 (1958) (Frankfurter, J., dissenting); West Virginia Bd. of Educ. v. Barnette, 319 U.S. 624, 646-47 (1943) (Frankfurter, J., dissenting).

84. 410 U.S. 113 (1973). 
of the majority Justices to persuade him to join with them, to harness his powerful conscientious objections to some appropriate judicial expression regarding the death penalty.

Blackmun might, of course, have been impervious to any such persuasive effort; his silent concurrence in McGautha (during his first Term as a Justice) suggests as much. Blackmun's dissent does not necessarily impeach the result in Furman. But as well as raising questions about the persuasive force mustered by the Justices in the majority, his dissent points to a larger failure of persuasion in Furman, a failure of unprecedented magnitude.

There was no opinion for the Court in Furman; but more than this, there was not even a plurality opinion. No Justice joined the opinion of any other in the majority. After a terse per curiam statement announcing the result reached, ${ }^{85}$ each of the five majority Justices wrote separate opinions giving individual reasons for coming to that result. None was persuaded to join in another's reasoning.

The Supreme Court had not been so visibly fragmented since its earliest days before Chief Justice Marshall took office and instituted the practice of issuing opinions "for the Court" 86 (and even then the early Justices' seriatim opinions could be read together more coherently than the Furman potpourri). Furman so starkly deviated from the traditional format that it can be characterized as a decision in which there was not only no Court opinion but no Court - only a confederation of individual, even separately sovereign, Justices. It was as if the nullifying impulse toward the death penalty that the Court ambivalently endorsed in Witherspoon had run rampant within the Court itself. Furman is not so much a culmination of the doubts expressed in Witherspoon about the propriety of the death penalty as it is an explosion of those doubts. (It is also an explosion of words; with the four dissenting opinions, Furman sprawls over 232 pages of the United States Reports, the longest single spread in the Court's history. ${ }^{87}$ )

85. 408 U.S. at $239-40$.

86. See G. GUNTHER, Constitutional Law 443 (11th ed. 1985) ("John Marshall persuaded his colleagues to abandon seriatim opinions."); D. O'BRIEN, supra note 48, at 108-09.

87. See Brennan, supra note 14, at 323. Numbers both of words and of opinions among the Justices have generally proliferated during the Burger Court years; Furman was an early, albeit extreme, indicator of the trend. See G. Casper \& R. POSNER, THE Workload of THE SUPREME COURT 80 (1976); D. O'BRIEN, supra note 48, at 264-66 ("When we compare the Burger Court's practice with that of forty years ago, we find ten times the number of concurring opinions, four times more dissenting opinions, and seven times the number of separate opinions. ... The Justices now care less about reaching a consensus on opinions for the Court.... Between 1901 and the last year of Chief Justice Warren, in 1969, there were 51 cases decided by plurality opinions. Between 1969 and 1984, however, the Burger Court handed down 111 plural- 
In its individualistic format, moreover, Furman is virtually a caricature of the isolated jury in death cases that Justice Brennan had condemned in McGautha - the jury that could not find common ground with other juries, for which no attempt was made to formulate coherent standards by which individual idiosyncracies might be tamed and the rule of law advanced. Whatever its practical attainability in jury deliberations, this goal did seem within reach in Furman if - but only if - Justices Brennan and Marshall had held to their views expressed in the McGautha dissent. In a footnote to his Furman opinion, Justice Douglas (who had also joined the McGautha dissent) outlined the majority opinion that might have been written: Add the three-man $M c$ Gautha dissent espousing a "'mechanism to prevent ... [jury] variation from reflecting merely random or arbitrary choice" "88 to the Furman opinions of Justice Stewart (arguing the death penalty was invalid because it was imposed on "a capriciously selected random handful") 89 and Justice White (finding "no meaningful basis for distinguishing" between those "few cases" where death was imposed "from the many" other death-eligible cases) ${ }^{90}$ and, Douglas suggested, we would have a majority opinion in Furman. But it was not to be, because, he lamented, "We are now imprisoned in the McGautha holding." $" 91$

This is a puzzling, if not inexplicable, complaint. Stare decisis surely did not "imprison" the Court in Furman, least of all Justice Douglas who had never previously seemed notably confined by constitutional precedent.92 It would have been more abrupt for the Court explicitly to reverse its year-old decision in McGautha than is the Court's custom in these matters. ${ }^{93}$ But this would have been more forthright than pretending that McGautha remained unimpaired as precedent. Furthermore, if the result of an explicit reversal had been

ity opinions, more plurality opinions than were rendered in the entire previous history of the Court.").

88. 408 U.S. at $248-49$ n.11 (Douglas, J., concurring) (quoting McGautha v. California, 402 U.S. 183, 248 (1971) (Brennan, J., dissenting)).

89. 408 U.S. at 248 n.11 (quoting Furman, 408 U.S. at 309-10 (Stewart, J., concurring)).

90. 408 U.S. at 248 n.11 (quoting Furman, 408 U.S. at 313 (White, J., concurring)).

91. 408 U.S. at 248.

92. For his view of its limited constitutional role, see Douglas, Stare Decisis, 49 Colum. L. REV. 735, 736-37 (1949); see also Maltz, supra note 3.

93. See Maltz, supra note 3, at 494-96. The closest precedent for such a quick reversal would have been the Court's much-maligned performance in the Legal Tender Cases, Knox v. Lee, 79 U.S. (12 Wall.) 457 (1871), overruling Hepburn v. Griswold, 75 U.S. (8 Wall.) 603 (1870), depicted as a "self-inflicted wound" in C. Hughes, The Supreme Court of the UNITED STATES 50-52 (1928). 
the creation of a coherent majority opinion for the Court, this would have had virtues beyond honesty.

As it was, the disarray on the Court in Furman ironically invited the same critique of that judicial decision that Justice Brennan aimed at the idiosyncratic jury decisions at issue in McGautha: that "in Lord Camden's words, it is 'the law of tyrants: It is always unknown: It is different in different men: It is casual, and depends upon constitution, temper, passion." "94 The rule of law - "to be worthy of the name"95 - is not an isolated individual enterprise but a communal endeavor in which idiosyncratic differences are reconciled and competing needs, interests, and passions harmonized.96 If this reconciliation, this harmony, is never ultimately attainable, the persistent mutual effort toward this goal is what distinguishes the rule of law from the law of tyrants. Furman failed to embody this ideal.

This failure can in part be ascribed to events within the Court itself that led to Furman. These internal events had eroded the Justices' own sense of institutional integrity and continuity, their belief that the Court was more than a collection of individual members pursuing individual ends. Justice Brennan has recently provided evidence to this effect in his 1986 Holmes Lecture by describing the erratic course of the Court's internal deliberation - a "path," as he put it, that "weaves and winds"97 - from Witherspoon to Furman. Brennan's account highlights the significance of a case decided during the Term between Witherspoon and McGautha. In Maxwell v. Bishop, ${ }^{98}$ two questions were argued: Whether the Constitution required specific standards for jury deliberations, and/or a bifurcated trial separating the issue of sentencing from guilt in capital cases. Brennan relates that at least five Justices - Warren, Douglas, Marshall, Fortas, and himself - agreed that bifurcation was required and that a sixth - Justice Harlan - indicated his strong inclination to this same effect. ${ }^{99}$ This Court majority suddenly dissolved, however, when Justice Fortas was forced to resign from the Court and was succeeded by Justice Blackmun who had previously written the circuit court opinion upholding

94. 402 U.S. at 285 (Brennan, J., dissenting) (quoting Hindson \& Kersey, cited in 8 State Tr. (Howell) $57 \mathrm{n}$.).

95. 402 U.S. at 285.

96. On the jurisprudential justification for this pursuit of mutual accommodation, see Burt, Constitutional Law and the Teaching of the Parables, 93 YALE L.J. 455, 481-89 (1984).

97. Brennan, supra note 14 , at 316 .

98. 398 U.S. 262 (1970).

99. Brennan, supra note 14, at 316. See also B. SchWARTZ, THE UNPUBLISHED OPINIONS OF THE WARREN COURT 412-37 (1985) (reprinting the draft opinions circulated within the Court). 
the death sentence in Maxwell itself. 100 Justice Harlan accordingly urged that the bifurcation issue await resolution in some subsequent case; and when the issue was argued the next Term in McGautha, Harlan had changed his mind and the contrary votes of Warren and Fortas in Maxwell were displaced by their successors, Burger and Blackmun.

If the Court majority for bifurcated capital trials had held in Maxwell, it would have been the second step, following the previous Term's decision in Witherspoon, toward an extended process of examining and incrementally restructuring the administration of the capital punishment system. As it happened, however, fortune intervened and the opportunity slipped away. Justice Brennan's retrospective account indicates that he was bitterly disappointed by this mischance. He relates that in conference deliberations he alone took the position that capital punishment was inherently violative of the eighth amendment and that Justices Douglas and Marshall in particular had clearly disagreed with him.101 Accordingly, when the ameliorative steps were rejected in McGautha, Brennan tried to forestall further Court adjudication on the ultimate eighth amendment issue, but without success; the Court granted certiorari in Furman. As Brennan subsequently recounted, with an ironically revealing slip of someone's pen, "We were clearly itching [sic] toward resolving what Justice Black had prematurely addressed in his $M c$ Gautha concurrence - namely, the meaning of 'cruel and unusual punishments' in the context of the death penalty ...."."102

Brennan approached Furman with foreboding: "In candor, I must admit that when McGautha was decided, I was convinced that it was not just a lost skirmish, but rather the end of any hope that the Court would hold capital punishment to be unconstitutional."103 When Furman was argued, however, the Court had yet again been dramatically transformed. Justices Black and Harlan were suddenly gone, and thus in less than two years President Nixon had chosen four Justices, apparently realigning the Court for a generation's time toward the rightward shift in public opinion that his election itself signified. Brennan's law clerks, meanwhile, had done preparatory summer research for an opinion in Furman which he "fully expected would be a lone dissent." In the fall, however, he was surprised to find that

100. Brennan, supra note 14 , at $317-18$.

101. Id. at 321.

102. Id.

103. Id. 
"there were signs that I might not be alone."104

After Furman was argued and the five separate opinions emerged from the respective Justices' chambers, none of them - least of all Justice Brennan - was prepared to reconsider this astonishing result from the perspective of the Court as an institution and try to link the result in Furman to the prior recent history of the Court's capital punishment decisions, or even to link one Justice to another in Furman itself. In the "weav[ing] and wind[ing]" of the "path from Maxwell v. Bishop, to McGautha v. California, to Furman v. Georgia," 105 the Court had lost its sense of itself as an institution with a continuous link between its past and future. The discontinuities of the Court's deliberations, magnified by the extensive changes in its membership, led the Justices constituting the Furman majority to approach the death penalty as if they were isolated both from one another and from any shared institutional history.

This isolation is antithetical to the ideal of the rule of law, an ideal whose intelligibility depends on the existence of a common language of principle arising from acknowledged continuity between a shared past and an anticipated future. ${ }^{106}$ The pursuit of this ideal in the broader society, and among the Justices themselves as a means toward and symbolic token of that broader social pursuit, was a distinguishing characteristic of the Warren Court. That Court's opinions might be confusing or obscure in conveying their precise holdings or rationales, as in Witherspoon and many other cases of the era.107 But in those cases the confusion reflected an internal Court process of accommoda-

104. Id. at 322 .

105. Id. at 316 .

106. See generally Fiss, Objectivity and Interpretation, 34 STAN. L. REv. 739 (1982).

107. Lack of clarity or precision was the common academic criticism of the Warren Court at the time. See Bickel \& Wellington, Legislative Purpose and the Judicial Process: The Lincoln Mills Case, 71 HARv. L. REv. 1, 3-6, 31-35 (1957); Kurland, Foreword: "Equal in Origin and Equal in Title to the Legislative and Executive Branches of the Government," 78 HARV. L. REV. $143,169-75$ (1964). These critics did not adequately grasp, however, that the very fuzziness of the customary Warren Court opinion reflected the Court's unarticulated attempt to find some middle ground among the polarized ideological and social disputes of the day. This characteristic was particularly evident in the Court's extension of Brown to other forms of social segregation without any explanation - an omission faulted by these critics, see Bickel \& Wellington, supra, at 4 , but justified within the Court as an attempt to avoid casting blame on Southern whites and thereby (as the Justices saw it) exacerbating more than helping to heal social conflict. See R. KLUGER, SIMPLE JUSTICE 706 (1975). Chief Justice Warren explicitly stated this goal in originally drafting the opinion in Brown itself; in a May 7, 1954, internal memorandum to the other Justices, he stated that the opinion should be "non-rhetorical, unemotional and, above all, nonaccusatory." Chief Justice Warren, Memorandum to Members of the Court (May 7, 1954), quoted in D. O'BRIEN, supra note 48 , at 281 . To work toward communal reconciliation was the implicit underlying strategy of the Warren Court's special solicitude toward social outcasts generally. See Burt, supra note 96 , at $481-82$. 
tion, a massing by the Justices toward some middle ground, however elusive. Furman suggested the abandonment of this enterprise.

For the Warren Court the most clearcut example of this enterprise was its work in race discrimination cases, especially regarding schools. From Brown until Warren's resignation, the Court spoke unanimously, when it spoke at all, in school desegregation cases. ${ }^{108}$ This unanimity did not come easily to the Justices; it was a calculated pursuit. ${ }^{109}$ Unanimity was not, of course, the Warren Court's standard for deciding all cases; but the effort toward mutual accommodation among the Justices, toward forging the most inclusive possible Court majority even at the sacrifice of individual victory or ideological clarity, was a characteristic mode. The unanimity of the school desegregation cases testified to the underlying impulse in the Warren Court just as the disarray of Furman spoke to the passing of that impulse with the end of the Warren Court. ${ }^{110}$ (From this perspective, it is tempting to say that the Burger Court is an oxymoron, that the Warren Court was succeeded by no court at all.)

The isolation of the majority Justices in Furman, and their inability to find some common ground that might also be sufficiently spacious to accommodate Justice Blackmun's conflicting concerns, implied larger issues that Justice Harlan addressed in his McGautha opinion. Insofar as the deliberative processes on the Court mirror the actuality or the aspirations of the broader society, Furman reiterated Harlan's implicit premise in McGautha that the tensions between Individual and Community, between Order and Justice, are irreconcilable.

The Court majority's embrace of this premise - explicit in $M c$ Gautha and implicit in Furman - reflects the apparent transformation of public mood that accompanied the end of the Warren Court era, the shift in opinion about whether American society was more polarized than unified. Deep social divisions were palpable during the Warren years. Divisions between blacks and whites, North and South, and rich and poor were among the most vividly acknowledged. The dominant attitude of these times however, was that these divisions could be healed or at least substantially ameliorated. This attitude was

108. The first dissents on the Supreme Court in a school desegregation case after Brown did not occur until 1973, in Keyes v. School Dist. No. 1, 413 U.S. 189 (1973).

109. See Hutchinson, Unanimity and Desegregation: Decisionmaking in the Supreme Court, 1948-1958, 68 GEo. L.J. 1 (1979).

110. Justice Stewart spoke to this change when, in a 1985 interview, he observed that "[t]he business of the Court is to give institutional opinions for its decisions" but that this "view has come [to] be that of a minority of the Justices." Interview with Associate Justice Stewart (Feb. 28,1985 ), quoted in D. O'BRIEN, supra note 48, at 214, 264. See also Cox, Foreword: Freedom of Expression in the Burger Court, 94 HARV. L. REV. 1, 72 (1980). 
apparent not only on the bench (e.g., in Brown v. Board of Education $)^{111}$ but in our public life generally (e.g., in the Great Society and its War on Poverty). ${ }^{112}$ The Warren Court ended as, for whatever concatenation of reasons, this optimism faded.

It is, I believe, not simple happenstance that questions about the legitimacy of the death penalty moved into more intense public and judicial awareness during these latter years of the Warren Court and the fading years of optimism about the possibilities for social reconciliation. Nor is it happenstance that the principal litigative agitator on these questions, the NAACP Legal Defense Fund, had been the central litigator in the black civil rights movement. Of all social practices, inflicting death on a transgressor is the most definitive and vivid affirmation that social conflict in the particular case is irreconcilable. Capital punishment is warfare writ small.

Peaceful reconciliation among adversaries is not always possible. War is sometimes inevitable. But warfare waged at large pushes everyone to the limits, and perhaps even outside, of the ordinary civil constraints that stand at the core of the "rule of law" ideal, no matter if that ideal is defined as socially harmonious Justice or as law-abiding Order. ${ }^{113}$ Whether capital punishment has the same implications in domestic life was the question pressed before the Court in these cases. Whether all of the palpable divisions in our domestic life seemed more to hold the possibility of explosive warfare than peaceful reconciliation was the underlying question that gave special visibility and symbolic force to the death penalty at this time. Whether the death penalty

11. 347 U.S. 483 (1954).

112. See W. Miller, The Fifteenth Ward and the Great Society 179, 183 (1966) (ascribing the Great Society legislation enacted in 1964-1965 to the disappearance of "rifts in society ... [that had] seemed ... wide" and to "a dramatic revival of social idealism and of serious public purpose").

113. Compare Judith Shklar's observation regarding the underlying implications of social dispute about the moral status of warfare. For those who believe in the possibility of a just war, she notes, "[w]ar is not outside the rules of law and morality, but is their extension into a disastrous extremity. As such it remains a normal, rule-governed collective activity." For those who reject this conception, however, war "falls in the realm of pure necessity, where the impulse to self-preservation extinguishes the very possibility of justice. It is the world of kill or be killed.... War, in this view, is not an extreme moral situation; it is wholly devoid of any moral compensation save personal courage." In such social disputes regarding the moral status of warfare, "neither can shake the other's convictions about the substance of their disagreement," and therefore the disputants

lack[] ... shared moral knowledge of any kind whatever. Each side [can only accuse the other] of hypocrisy, which was merely a failure to live up to its own standards, not a failure to meet mutually recognized obligations.

This is the normal character of political discourse between irreconcilable ideological opponents within societies that are so free that wars can be discussed openly even while they are being waged. In times of such stress, the intensity of recriminations is naturally great.... [These recriminations do] not imply shared knowledge, but mutual inaccessibility.

J. ShKLAR, ORDINARY Vices 80-81 (1984). 
should be abolished as a token of our continued faith in social reconciliation even in the most extreme conflicts or whether it should be reaffirmed, even strengthened, as a response to irreconcilable domestic conflict generally - this was a question not resolved but signified by the Court's disarray in Furman.

\section{Phase II: DoubTs Appeased}

Four years after Furman, the Supreme Court again addressed the constitutionality of capital punishment. During this interval, thirtyfive state legislatures had reenacted death penalty laws in response to Furman. ${ }^{114}$ In Gregg v. Georgia ${ }^{115}$ and companion cases from Florida, ${ }^{116}$ Texas, ${ }^{117}$ North Carolina, ${ }^{118}$ and Louisiana, ${ }^{119}$ the Justices approved some and disapproved others. Unlike Furman, each of the Justices did not speak or vote alone. As in Furman, however, there was no Court at work. The judgments resulted from an aggregation of plurality voting lacking any majority rationale to explain the different outcomes in these cases.

Two Justices - Brennan and Marshall - voted to invalidate the death penalty laws in all of these cases ${ }^{120}$ and four - Chief Justice Burger, and Justices White, Blackmun, and Rehnquist - voted to uphold all of them. ${ }^{121}$ Three Justices were in the middle, as it were Stewart, Powell, and Stevens (who had succeeded Douglas). These three voted to uphold the Georgia, Florida, and Texas statutes that specified various substantive standards for jury discretion ${ }^{122}$ and to invalidate the North Carolina and Louisiana statutes that purported to abolish jury discretion by mandating death as the penalty for specific criminal offenses. ${ }^{123}$

114. See Gregg v. Georgia, 428 U.S. 153, 232 (1976) (Marshall, J., dissenting).

115. 428 U.S. 153 (1976).

116. Proffitt v. Florida, 428 U.S. 242 (1976).

117. Jurek v. Texas, 428 U.S. 262 (1976).

118. Woodson v. North Carolina, 428 U.S. 280 (1976).

119. Roberts v. Louisiana, 428 U.S. 325 (1976).

120. Gregg, 428 U.S. at 227 (Brennan, J., dissenting); Woodson, 428 U.S. at 305-06 (Brennan, J., concurring); Gregg, 428 U.S. at 231 (Marshall, J., dissenting); Woodson, 428 U.S. at 306 (Marshall, J., concurring).

121. Gregg, 428 U.S. at 207 (White, J., joined by Burger, C.J., and Rehnquist, J., concurring); Proffitt, 428 U.S. at 260 (same); Jurek, 428 U.S. at 277 (same); Gregg. 428 U.S. at 227 (Blackmun, J., concurring); Proffitt, 428 U.S. at 261 (same); Jurek, 428 U.S. at 279 (same); Woodson, 428 U.S. at 306 (White, J., joined by Burger, C.J., and Rehnquist, J., dissenting); Woodson, 428 U.S. at 307 (Blackmun, J., dissenting); Roberts, 428 U.S. at 337 (White, J., joined by Burger, C.J., Blackmun, and Rehnquist, JJ., dissenting).

122. Gregg, 428 U.S. at 158; Proffitt, 428 U.S. at 244; Jurek, 428 U.S. at 264.

123. Woodson, 428 U.S. at 282; Roberts, 428 U.S at 327. 
Gregg showed the continued significance and even intensifying force since Furman of polarization both within the Court and in individual Justices' views of American society generally. The Justices writing in Gregg believed they had learned something about American society in the interim between 1968, when the Court in Witherspoon suggested that death penalty supporters were a "distinct and dwindling minority," 124 and 1976, when thirty-five state legislatures responded to the Court's action in Furman by reenacting various death penalty statutes. These legislative actions may have been more a reflexive response to the provocation from the Court than an accurate reflection of contemporary public attitudes. ${ }^{125}$ Nonetheless, the Justices gave considerable - some even dispositive - significance to this legislative reaction.

Justice Marshall was explicit: "I would be less than candid if I did not acknowledge that these [legislative] developments [since Furman] have a significant bearing on a realistic assessment of the moral acceptability of the death penalty to the American people."126 Marshall did not, however, alter his previous conclusion in Furman about the unconstitutionality of capital punishment. He instead took a different tack to argue for that conclusion, stating that current expressions of public sentiment were not "the opinion of an informed citizenry" and "if [citizens] were better informed they would consider [capital punishment] shocking, unjust, and unacceptable."127

Marshall was clearly affected by his perception that he and the predominant American public were far apart. He did not reiterate in Gregg the faith in his "fellow citizens" that he had expressed four years earlier in Furman:

There is too much crime, too much killing, too much hatred in this country. If the legislatures could eradicate these elements from our lives by utilizing capital punishment, then there would be a valid purpose for the sanction and the public would surely accept it.... What purpose has it served? The evidence is that it has served none. I cannot agree that the American people have been so hardened, so embittered that they want to take the life of one who performs even the basest criminal act knowing that the execution is nothing more than bloodlust. This has not been my experience with my fellow citizens. Rather, I have found that

124. Witherspoon v. Illinois, 391 U.S. 510,520 (1968).

125. See F. Zimring \& G. Hawkins, Capital Punishment and the american AGENDA 41-45 (1986). On the malleability of public opinion regarding the death penalty, see Sarat \& Vidmar, Public Opinion, the Death Penalty, and the Eighth Amendment: Testing the Marshall Hypothesis, 1976 WIs. L. REv. 171, 191, 196; Vidmar \& Ellsworth, Public Opinion and the Death Penalty, 26 STAN. L. Rev. 1245, 1264-68 (1974).

126. Gregg, 428 U.S. at 232 (Marshall, J., dissenting).

127. 428 U.S. at 232 (emphasis in original). 
they earnestly desire their system of punishments to make sense in order that it can be a morally justifiable system. ${ }^{128}$

The rapid response to Furman by the thirty-five legislatures seemed for Marshall to signify little more than thoughtless bloodlust, evidence that legislators and his fellow citizens were not as earnest, as decent as he had hoped - that they indeed had become "hardened" and "embittered" as he had feared. Against this desolate vision of the society in which he lived, Marshall saw a role for himself as a judge. He had already depicted this role in his Furman opinion:

At times a cry is heard that morality requires vengeance to evidence society's abhorrence of [a particularly offensive] act. But the Eighth Amendment is our insulation from our baser selves. ...

... [O]nly in a free society would men recognize their inherent weaknesses and seek to compensate for them by means of a Constitution. ${ }^{129}$

Thus in Gregg, as he had in Furman, Marshall invoked the eighth amendment to invalidate the death penalty as such, but in Gregg he did so without illusion that his action would find widespread public approbation. Not only did he see himself hostile to and alienated from the dominant forces in his society; he saw alienation and hostility "our baser selves" - as the prevailing attitudes in American society.

Justice Brennan was not as open as Marshall in portraying his society and his relationship to it. But his actions conveyed the same underlying vision as Marshall's words. Brennan's dissent in Gregg contained some hint, at least, that he not only saw himself in a losing minority but also that his alienation from the majority was so deep as to be almost irremediable. His dissent conveyed this suggestion not in what he said but in what he did not even bother to say. Brennan's dissent occupies barely five pages in the United States Reports. ${ }^{130}$ Even of this, one full page is a verbatim quotation from his previous separate opinion in Furman. ${ }^{131}$ His dissent is perfunctory, as if nothing would be gained by arguing for his position, no matter how rigorously, how passionately.

To be sure, Brennan's Furman opinion was extensive and his Gregg dissent came to the same conclusion about the eighth amendment. This was the basis on which Brennan justified his brevity in Gregg: "I shall not again canvass the reasons that led to that conclusion." 132

128. 408 U.S. at 370 n. 163 (Marshall, J., concurring).

129. 408 U.S. at $344-45$.

130. 428 U.S. at 227-31 (Brennan, J., dissenting).

131. 428 U.S. at 228.

132. 428 U.S. at 229. 
But much had happened in the four-year interim. Brennan might have addressed the implications for his previous position on the actions of the thirty-five legislatures, particularly the ways in which his constitutional analysis in Furman directly applied to the specific provisions of the five newly enacted state statutes directly before the Court, the significance of the differences among these statutes, and the coherence of the differing dispositions of his brethren regarding these five statutes. Brennan did none of this. It was as if he had left the enterprise of reasoned argument, abandoning any hope that his arguments might persuade those inclined to oppose him. Brennan acted as if he were a member of a deeply and irremediably polarized society where conversation consisted merely of demands and adamantly proclaimed fiats, rather than of persistent appeals for mutual understanding and reasoned efforts to persuade.

There was only a hint of this implication in Gregg. In the subsequent dissents of Brennan and Marshall - coming in every death penalty case where certiorari was denied - the implication was drawn out almost explicitly, in an almost caricatured form. In the nine years following Gregg, the two Justices issued such dissents in some four hundred cases, ${ }^{133}$ almost invariably with the same formulaic statement: "Adhering to our views that the death penalty is in all circumstances cruel and unusual punishment prohibited by the Eighth and Fourteenth Amendments, we would grant certiorari and vacate the death sentences in these cases." 134

There is an unacknowledged oddity in these dissents. Given that the Court majority had long since rejected the Brennan-Marshall position, determining the constitutional validity of any death penalty provision required the majority to undertake a complicated, detailed assessment in every case; and if the Court were to accept review in every death penalty case, it is difficult to understand how the Justices could find time for any other business. Brennan and Marshall had thus set themselves outside the deliberative processes by which the Justices analyze the competing significance of the particular cases where review is sought. ${ }^{135}$

This does not demonstrate that Brennan and Marshall were unjus-

133. E. Villarreal, Dissents to the Denial of Certiorari in Death Penalty Cases of Justices Brennan and Marshall (July 11, 1985) (unpublished Yale Law School seminar paper) (listing results of LEXIS search).

134. E.g., Celestine v. Blackburn, 472 U.S. 1022 (1985) (Brennan and Marshall, JJ., dissenting from denial of certiorari) (citation omitted); Adams v. Florida, 439 U.S. 947 (1978) (same); Rust v. Nebraska, 434 U.S. 912 (1977) (same).

135. Cf. SuP. Cr. R. 19; Linzer, The Meaning of Certiorari Denials, 79 Col.uM. L. REv. 1227, 1248-51 (1979). 
tified in their certiorari dissents. They were persistently protesting against ever viewing any particular imposition of the death penalty as sufficiently "settled practice," as raising "merely routine" issues, so as not to warrant review by the highest constitutional tribunal. My point is not that they were wrong, but that they were visibly and even willfully isolated, alienated. Their persistent dissents were a kind of vigil against the death penalty, even virtually a silent vigil — closer to the tradition of civil disobedients who see themselves as prophets in a wilderness than to the conventional social role of "insider" that their high judicial office ordinarily would denote. ${ }^{136}$

This same stark conception of American society - as a place of such hostile divisions as almost to moot the possibilities of mutual forbearance and persuasion - was conveyed in Gregg by another Justice who had served on the Warren Court. Justice White did not, however, lament this characterization or stand against it; he virtually relied on it as the basis for changing his vote from Furman and upholding the constitutionality of all the death penalty statutes in Gregg.

In his Furman opinion, Justice White criticized the statutes at issue on the ground that there was "no meaningful basis for distinguishing" between cases where juries imposed or withheld death sentences. ${ }^{137}$ But his position in the Gregg series made clear that this was not his fundamental complaint in Furman. His basic objection was that the statutes challenged in Furman did not demonstrate that state legislatures were seriously intent on imposing death in any case. Because of the open-ended discretion in their statutes, he observed in Furman that the "legislative will is not frustrated if the penalty is never imposed";138 and since the penalty in practice was imposed "with great infrequency even for the most atrocious crimes,"139 White could see no social purpose for its application in those rare events. ${ }^{140}$ For White, it was not the absence of standards that condemned the statutes; it was the absence of a tough-minded will among state officials to use execution as an instrument of social policy.

This taste for the draconian had indeed been White's basic position in his Witherspoon dissent. He argued there that states should be free to exclude any juror who showed even the slightest hesitation to vote

136. See generally R. BURT, Two JeWish Justices: OUtCAsts IN THE Promised LAND (forthcoming).

137. 408 U.S. at 313 (White, J., concurring).

138. 408 U.S. at 311.

139. 408 U.S. at 313.

140. 408 U.S. at 312. 
for death in order to convene a jury inclined to favor that sentence. ${ }^{141}$ Prejudice as to guilt would be constitutionally impermissible, White stated, but there is no constitutional bar to jury prejudice regarding the "determination of sentence, even when that sentence is death." 142

For White, then, the reenactment of death penalty laws by thirtyfive states in the immediate wake of Furman was sufficient indication of toughened purpose. The specific details of the statutes - whether mandatory or discretionary, whether or not confined by tight substantive standards and elaborate appellate processes - were beside the point. Having obtained this indication of strong intent, the Court's role as he saw it was to step aside for the states' undertaking to proceed as promised.

White's position in these cases is reminiscent of the attitude expressed in some quarters about American military policy during the Vietnam War - that if we were truly engaged in war then we should be prepared to use every weapon at our disposal, but if we had no real taste for warfare then we should abandon the enterprise. ${ }^{143}$ White may not have believed, as did these advocates for military force, that active deployment of the capital punishment weapon would bring victory in the war against crime. This issue was, however, irrelevant for White's constitutional analysis. His test required that the states show their belief in its efficacy rather than prove it to him, that they pursue their mission as if it were active warfare but not necessarily demonstrate clear prospects for victory. ${ }^{144}$ In this sense, White was prepared to validate the constitutionality of capital punishment only if he were convinced that a legislative majority saw the struggle against criminals as open warfare in American society.

White's belief that citizens saw themselves as fundamentally divided, as irremediably hostile toward one another, was crucial to his willingness to accept capital punishment. This was precisely the characterization that led Marshall and Brennan to the opposite conclusion - to invalidate the death penalty as "insulation from our baser

141. Witherspoon, 391 U.S. at $541-42$ (White, J., dissenting).

142. 391 U.S. at 541.

143. See A. Schlesinger, JR., The Bitter Heritage: Vietnam and American DeMOCRACY 1941-1966, at 50 (1967) (quoting Senator Richard Russell of Georgia, chairman of the Senate Armed Services Committee, who said that "we should go in [to Vietnam] and win - or else get out," and citing public opinion polls that documented "increased militancy about the Vietnam war and a get-it-over-with mood").

144. Cf. Carey v. Population Servs. Intl., 431 U.S. 678, $702-03$ (1977) (White, J., concurring) (providing similar justification for invalidating state legislation prohibiting distribution of contraceptives to minors). But sec Bowers v. Hardwick, $106 \mathrm{~S}$. Ct. $284 \mathrm{I}$ (1986) (upholding criminal laws against private, consensual sodomy notwithstanding the general laxness of state enforcement). 
selves." 145

Justice Stewart tried to find a middle ground between White's draconian position and Brennan and Marshall's abolitionism. Stewart's effort was propelled by the same vision of hostile division in American society that lay behind the other Justices' positions, but this vision led Stewart to different results. It furnished the basic, though only implicit, rationale for the distinction Stewart drew between his disapproval of mandatory death penalty statutes and his approval of statutes providing standards to guide jury discretion.

The virtue of this supposed middle ground for Stewart was that it promised to dampen and even to obscure the social conflict that he believed, or at least feared, he saw. This effort to avert open expression of social conflict is the one unifying thread that runs through Stewart's positions in all of the death penalty cases. It best explains why he voted with Brennan and Marshall in Witherspoon but against them in McGautha, with them in Furman but against them in Gregg. In all these cases, Stewart appeared to nurture the same hope that animated Brennan and Marshall: the hope that this society was fundamentally compassionate and peaceable, not divided by implacable hostilities. This hope seemed to lead Stewart, after concluding in Witherspoon that death penalty supporters were a "distinct and dwindling minority," 146 both to explain and to applaud this imagined state by citing Arthur Koestler's observation that the division between death penalty opponents and supporters was "between those who have charity and those who have not."147

But Stewart's faith in the accuracy of this fundamentally peaceable characterization of American society was always more tentative than Brennan's or Marshall's; Stewart was less willing than they to subject this characterization to the risks of overt, explicit testing. This is the underlying reason, I surmise, that led Stewart to vote with Harlan in McGautha against requiring legislative standards.

Brennan's dissenting position in McGautha, if adopted by a Court majority, would have focused public attention on the death penalty both in the legislative proceedings to draft the specific standards he demanded and in the subsequent, rigorously detailed appellate review of the rationality of any such standards. In retrospect, it appears that Brennan hoped, perhaps even expected, that if this extended public scrutiny were demanded by the Court the process ultimately would

145. Furman, 408 U.S. at 345 (Marshall, J., concurring); see also 408 U.S. at 295-96 (Brennan, J., concurring).

146. 391 U.S. at 520.

147. 391 U.S. at 520 n.17. 
lead to a definitive popular rejection of the death penalty. Stewart, however, seemed to pursue a different strategy: if the death penalty ultimately were to be abolished, as his Witherspoon opinion suggested he hoped, this result most likely would come by indirection rather than by clearcut public confrontation. Mandating the inclusion of death penalty opponents on juries, to the extent envisioned by Witherspoon, would promote this result; challenging legislatures to draft death penalty standards would work against this result.

Stewart's position in Furman can also be explained from this perspective. If, as he seemed to believe in Witherspoon, popular support for capital punishment was already weak and diminishing, the best route toward abolition would be a swift coup, so swift that potential adversaries would hardly know where the blow originated or how it might be countered. The judicial version of such a coup would be an unexpected decision supported by a short and virtually unintelligible opinion. This surely describes Stewart's brief opinion in Furman, comprised only of six introductory paragraphs explaining what he was not deciding ${ }^{148}$ and three subsequent paragraphs leading to his conclusion that "this unique penalty [is] . . . so wantonly and so freakishly imposed" that its recipients appear simply to have been "struck by lightning." 149 One might say that his opinion itself was like a stroke of lightning: it appeared suddenly to illuminate a landscape but as quickly yielded to darkness.

An adamant proponent of capital punishment, determined to rescue the penalty from this condemnation, might find some hope in Stewart's opinion for a less "wanton" or "freakish" reenactment; but there was no invitation there, no clear road map to be followed to that end. Nonetheless, the route was not clearly barred as in Brennan and Marshall's Furman opinions. Stewart's opinion was a tentative, indirect - almost a sneak - attack on the death penalty, much like Witherspoon.

The question remains, however: if this was Stewart's strategy, why did he choose in Furman to mount this kind of attack when he already had launched Witherspoon, which promised to undermine the penalty almost invisibly by manipulating the composition of juries? Two related explanations are possible. First, some lower courts had by then apparently eviscerated the Witherspoon directive. ${ }^{150}$ The Supreme

148. 408 U.S. at 306-08 (Stewart, J., concurring).

149. 408 U.S. at 309-10.

150. See Bell v. Patterson, 402 F.2d 394 (10th Cir. 1968), cert. denied, 403 U.S. 955 (1971); State v. Mathis, 52 N.J. 238, 245 A.2d 20 (1968), revd. mem., 403 U.S. 946 (1971); M. MELTSNER, supra note 2, at 125. 
Court, to be sure, might have redoubled its efforts by accepting review of these cases and elaborating its doctrine, but for whatever reasons, four members of the Court were not prepared to vote for certiorari.

Second, at this same time, the numbers of condemned prisoners were mounting ominously. There had been no executions anywhere in the country since 1967, the year before Witherspoon was decided; this was the work of abolitionist litigators who had pieced together an effective nationwide moratorium from several lower courts on the ground that the Supreme Court was engaged in examining all aspects of the capital punishment system. ${ }^{151}$ By 1972, these litigators apparently had met defeat in the Supreme Court on every issue that might prolong this moratorium but for the question presented in Furman, whether capital punishment as such violated the eighth amendment. As both the litigators and the Justices saw it, if Furman rejected this last challenge, a sudden explosion - a bloodbath - of executions might erupt. Justice Marshall explicitly noted his concern about this prospect: "Candor compels me to confess," he said, "that I am not oblivious to the fact that ... [this case] [n] ot only ... involve[s] the lives of these three petitioners, but those of the almost 600 other condemned men and women in this country currently awaiting execution."152

If, as I have speculated, Justice Stewart at this time would have preferred the Court to sustain a stately progression toward an almost unnoticed withering away of capital punishment, it would follow that he would feel something had to be done to avert the execution of this massed number. Moreover, if the death penalty remained in force only because of an institutional lag between legislative action and public support for abolition (as Stewart's opinion in Witherspoon implied), then mass executions were particularly offensive - not only as an affront to notions of fairness but as a provocation to public sensibilities, a needless fomenting of social conflict.

This is the route, the internally consistent position, that can be traced for Stewart from Witherspoon to McGautha to Furman: if he wanted to abolish the death penalty, he wanted even more to avert openly waged public conflict about it. If this wish inclined Stewart to favor the abolitionist position in Witherspoon and Furman, this was not necessarily because of his personal sympathies but more because capital punishment seemed to him like some aged dinosaur: socially useless, destined for extinction, but still visibly, provocatively, destruc-

151. M. MELTSNER, supra note 2, at 107-09, 126-48.

152. 408 U.S. at 316 (Marshall, J., concurring). 
tively thrashing about. His vote in Furman was not so much to kill the beast as to offer it a decent, peaceful burial.

But the beast would not die. This was the meaning that Stewart ascribed in Gregg to the response of the thirty-five legislatures reenacting death penalty statutes:

The petitioners ... renew the "standards of decency" argument, but developments during the four years since Furman have undercut substantially the assumptions upon which their argument rested. Despite the continuing debate, dating back to the 19th century, over the morality and utility of capital punishment, it is now evident that a large proportion of American society continues to regard it as an appropriate and necessary criminal sanction. ${ }^{153}$

Stewart thus backhandedly acknowledged that his estimation of public attitudes was also incorrect in Witherspoon. But this changed evaluation did not lead Stewart to change his basic strategy, to alter his conception of his proper role as a judge in addressing capital punishment. In Gregg, as in the previous cases, his fundamental pursuit was still to dampen and even to disguise public conflict about the death penalty.

Stewart was, however, ambivalent about the means for achieving this result: whether to build on the Witherspoon strategy (as adumbrated in Justice Brennan's McGautha dissent) by incrementally constricting the application of the death penalty or to withdraw from any constitutionally based supervision of the death penalty, though also only in incremental steps that would effectively disguise the Court's return to its holding in McGautha. This ambivalence is apparent in Stewart's opinions regarding the various state statutes reviewed in the Gregg series. Stewart was joined in these opinions by Justices Powell and Stevens. In retrospect, it appears that Powell was more clearly inclined toward a masked reaffirmation of McGautha while Stevens leaned toward Witherspoon and Brennan's McGautha dissent. But this difference became apparent only much later, after Stewart had retired from the Court in 1981. Until then these three Justices voted together in most of the death penalty decisions after Gregg, and the ambivalence of Gregg remained unresolved.

In Gregg itself, the first of the series decided on the same day in 1976, that ambivalence is not apparent. Stewart's opinion upholding the Georgia statute read as if he wholeheartedly embraced Brennan's McGautha dissent. Stewart stated that there was "substantial tension" between his current opinion and McGautha. ${ }^{154} \mathrm{He}$ favorably cited

153. Gregg, 428 U.S. at 179.

154. 428 U.S. at 196 n.47. 
Brennan's dissent. ${ }^{155} \mathrm{He}$ even made an effort, though obviously feeble, to distinguish the two cases: "McGautha's assumption that it is not possible to devise standards to guide and regularize jury sentencing in capital cases has been undermined by subsequent experience."156 The only "subsequent experience" available was, of course, the thirty-five states' efforts to respond to the Court's ruling in Furman; this experience no more demonstrated the efficacy of sentencing standards than, as the old joke put it, a man's belief in baptism is vindicated by the fact that he's "seen it done."

Stewart could actually see, however, some elements in the newly enacted state statutes that offered more than unquestioning faith as a basis for believing in the possible efficacy of sentencing standards. In Gregg itself, the Georgia legislature in fact had made a serious effort to comply with the kind of strictures that Brennan had proposed in his McGautha dissent. Georgia established a bifurcated sentencing procedure; provided a list of ten "statutory aggravating circumstances," from which at least one must be explicitly found to justify a death sentence; mandated direct review in the state supreme court of the evidence supporting the enumerated aggravating circumstances and of the "excessive or disproportionate" relation of the sentence with "the penalty imposed in similar cases"; and established a specially staffed office to assist the appellate court in considering proportionality by gathering records of all death penalty cases in the state. ${ }^{157}$ Brennan's McGautha dissent had required no more than this. Indeed, the establishment of a special administrative office to assist the state supreme court in its review functions was more than he had asked, though consistent with the spirit of his opinion.

The Florida statute, also before the Court in the Gregg series, took a different but no less serious tack in devising standards. Beyond the specification of statutory aggravating and mitigating standards, the basic jury-controlling device in the Florida statute was to provide that the jury was only advisory; the judge alone determined sentence and must write a reasoned opinion in imposing death. ${ }^{158}$ Interpreting this statute, the Florida supreme court had held that on review it would "determine independently" 159 whether the death sentence was justified and, moreover, would undertake the same comparative inquiry re-

155. 428 U.S. at 195 n.45.

156. 428 U.S. at 196 n.47.

157. 428 U.S. at $165-67 \&$ n. 10 .

158. Proffit v. Florida, 428 U.S. 242, 249-50 (1976).

159. 428 U.S. at 253 (citing Songer v. State, 322 So. 2d 481, 484 (Fla. 1975)). 
garding other death cases that was statutorily mandated in Georgia. ${ }^{160}$ Thus, Florida too made a plausible attempt to meet the strictures that Brennan's $M c G a u t h a$ dissent proposed.

If Justice Stewart had approved only the Georgia and Florida statutes in the Gregg series, there would be no basis for finding him less intent than Brennan in McGautha to control jury discretion. There was, however, a third statute in the Gregg series that Stewart also approved, and here his fundamental ambivalence becomes apparent. Like Georgia and Florida, the Texas statute provided for a bifurcated sentencing procedure, ${ }^{161}$ but beyond this, there was little assured similarity. The Texas statute posed three questions to the jury: whether the defendant had "deliberately" caused death; "whether there is a probability that the defendant would commit criminal acts of violence that would constitute a continuing threat to society"; and whether, if the victim had provoked the defendant, nonetheless the defendant's killing was an "unreasonable" response. ${ }^{162}$ If the jury answered these three questions affirmatively, a death sentence would automatically be imposed. In most cases only two of these questions would be at issue, and these two would reduce themselves to this: was the defendant guilty of deliberate murder and was there "a probability" that he would commit additional violent crimes?

This statute reads as if the Texas legislature had purposefully set out to prove Justice Harlan's assertion in McGautha that statutory standards would inevitably be "either meaningless 'boiler-plate' or a statement of the obvious that no jury would need."163 In the Texas statute, moreover, there was no provision for comparative appellate review of death penalty cases and no indication from the responsible tribunal, the state court of criminal appeals, that it intended to engage in such review. ${ }^{164}$

One of the Justices dissenting in the Gregg series indeed observed that this Texas statute "seems as likely as any to produce ... unbridled discretion." 165 This was not the observation of Justices Brennan or Marshall, however; they were preoccupied in that case with the

160. 428 U.S. at 250-51 (citing State v. Dixon, 283 So. $2 d$ 1, 10 (Fla. 1973)).

161. Texas v. Jurek, 428 U.S. 262, 269 (1976).

162. 428 U.S. at 269.

163. 402 U.S. at 208.

164. See Jurek, 428 U.S. at 269, 272-73. In their opinion, Stewart, Powell, and Stevens tried lamely, however, to stretch the Texas appellate scheme into the Georgia/Florida mold: "By providing prompt judicial review of the jury's decision in a court with statewide jurisdiction, Texas has provided a means to promote the evenhanded, rational, and consistent imposition of death sentences under law." 428 U.S. at 276.

165. Woodson v. North Carolina, 428 U.S. 280, 316 (1976) (Rehnquist, J., dissenting). 
bigger fish of abolishing the death penalty outright and thus were inattentive to the possible differences among the specific state statutes under review. The dissenter who critically characterized the Texas statute was Justice Rehnquist; and he was arguing only that if it were constitutionally valid, then all of the statutes in the Gregg series, including the so-called mandatory imposition statutes from North Carolina and Louisiana, were indistinguishable and thus also valid. ${ }^{166}$

Whatever the possible distinctions between the Texas statute and these two others, it is clear that Texas did not take the pains even on the face of its statute that Georgia and Florida had taken to present a "carefully drafted statute"167 that held clear promise "to guide and regularize" death sentencing. ${ }^{168}$ Justice Stewart's willingness to swallow the Texas statute indicated that, notwithstanding his protestations, his position might not be in "substantial tension" with Harlan's reasoning for the majority in McGautha. Harlan had said that jury discretion could not be effectively constrained; legislative drafting exercises would at most produce only an appearance of constraint. In approving the Texas statute five years later, Justice Stewart at least suggested that he was willing to settle for appearances.

The possibility that Stewart in the Gregg series was merely settling for appearances, spreading an obscuring blanket of seeming regularity over jury deliberations in death cases, was suggested even more clearly in his disposition of the two remaining state statutes at issue in the Gregg series. Unlike the others, the North Carolina and Louisiana statutes wholly eliminated sentencing discretion from judge or jury; if the jury found the defendant guilty of certain specified crimes, then the death penalty necessarily followed. ${ }^{169}$ Stewart found such mandatory regimes "unduly harsh and unworkably rigid."170 They "simply papered over the problem of unguided and unchecked jury discretion."171 This was because, Stewart maintained, jurors opposed to or uncomfortable with the death penalty would not faithfully follow the statutory directives; they would nullify these directives, with full knowledge that they were violating the law. For this reason, he said, mandatory statutes "may well exacerbate the problem identified in Furman by resting the penalty determination on the particular jury's

166. 428 U.S. at 314-16.

167. Gregg, 428 U.S. at 195.

168. 428 U.S. at 196 n. 47.

169. Woodson, 428 U.S. at 285-86; Roberts v. Louisiana, 428 U.S. 325, 331 (1976).

170. Woodson, 428 U.S. at 293.

171. 428 U.S. at 302. 
willingness to act lawlessly."172 A mandatory statute "plainly invites the jurors to disregard their oaths and choose a verdict for a lesser offense whenever they feel the death penalty is inappropriate."173

At the same time, Stewart was equally concerned by the prospect of lawless conduct from supporters of the death penalty. He was also explicit about this in his Gregg opinion upholding the discretionary statutes:

In part, capital punishment is an expression of society's moral outrage at particularly offensive conduct. This function may be unappealing to many, but it is essential in an ordered society that asks its citizens to rely on legal processes rather than self-help to vindicate their wrongs. ${ }^{174}$

At this point, Stewart reiterated a passage which had first appeared in his opinion in Furman:

"The instinct for retribution is part of the nature of man, and channeling that instinct in the administration of criminal justice serves an important purpose in promoting the stability of a society governed by law. When people begin to believe that organized society is unwilling or unable to impose upon criminal offenders the punishment they 'deserve,' then there are sown the seeds of anarchy - of self-help, vigilante justice, and lynch law." 175

In these cases, as in the entire course of his death penalty jurisprudence, Stewart persistently tried to find some middle ground between the polarities represented by the staunchest proponents and opponents of the death penalty. Unlike Marshall and Brennan, he wanted to "channel" the popular retributive instinct rather than attempt to suppress it as a constitutionally unworthy expression of "our baser selves" (as Marshall had put it). ${ }^{176}$ But unlike other Justices, White notably included, ${ }^{177}$ Stewart was not prepared to give free rein to this popular impulse to override opposing minority sentiment. By invalidating the mandatory statutes, Stewart blunted a highly visible, clear-cut, and strong public approbation of the death penalty - and its apparent conclusive resolution of the controversy. By insisting that juries must have discretion to impose or withhold death sentences, Stewart reopened - but also buried - the controversy. Stewart's essential mission thus was to dampen and obscure social conflict by appeasing both proponents and opponents of capital punishment.

When Justice Brennan had proposed in McGautha that the Court

172. 428 U.S. at 303.

173. Roberts, 428 U.S. at 335.

174. Gregg, 428 U.S. at 183 (footnote omitted).

175. 428 U.S. at 183 (quoting Furman, 408 U.S. at 308 (Stewart, J., concurring)).

176. Furman, 408 U.S. at 345 (Marshall, J., concurring).

177. See text at notes 137-45 supra. 
require legislatures to devise standards to guide jury discretion, this had been a challenge to legislatures (and reviewing appellate courts in turn) to engage in a detailed public exploration of the proper uses of capital punishment - in effect, it was a provocation for visible public dispute about a previously obscured issue. When Justice Stewart declared in the Gregg series that the Texas statute satisfied the constitutional norms of adequate standards and appellate supervision, his position had a significance diametrically opposed to Brennan's challenge in McGautha. Stewart was apparently inviting state legislatures to revive the very technique that had previously hidden the capital punishment dispute from public view - to mask the administration of the death penalty in individually isolated, inscrutable jury deliberations. He thus seemed to invite a return to the status quo ante bellum, to the time before the litigation and its visibly attendant public controversy had erupted in the late sixties.

This was not, however, unequivocally stated in the Gregg series. Nor was it clear in the immediate aftermath of Gregg that Stewart himself, or a majority of the Justices, had come to this conclusion. For some seven years after Gregg, the Court's decisions did seem to reflect an intense scrutiny and an incrementally progressive cabining of the death penalty.

Of the fifteen capital cases fully argued and decided on the merits by the Court until 1982, all but one reversed or vacated the death sentence as imposed.178 The Court's rulings during this time narrowed the application of the penalty to murderers, explicitly excluding rapists, 179 and to those who intended to kill, excluding co-felons vicariously liable for murder. ${ }^{180}$ The Court also struck down any limitations on the kinds of mitigating evidence a defendant might present to the sentencer ${ }^{181}$ and overturned restrictions on the defendant's access to all information before the sentencer. ${ }^{182}$ The Court's rationale for these rulings was often obscure both because the decisions were frequently based on agglomerations of plurality and concurring opinions ${ }^{183}$ and because the individual opinions themselves were not models of lucid exposition. None of these decisions required radical change in the basic workings of the state capital punishment regimes;

178. Weisberg, supra note 49 , at 305 n.1.

179. Coker v. Georgia, 433 U.S. 584 (1977).

180. Enmund v. Florida, 458 U.S. 782 (1982).

181. Lockett v. Ohio, 438 U.S. 586 (1978).

182. Gardner v. Florida, 430 U.S. 349 (1977).

183. See e.g., Coker v. Georgia, 433 U.S. 584 (1977); Gardner v. Florida, 430 U.S. 349 (1977); Lockett v. Ohio, 438 U.S. 586 (1978). 
nonetheless, these kinds of small-gauge rulings, if sustained over a long period, could have had a considerable impact.

The most intriguing of the Court's decisions during this period was Godfrey v. Georgia, ${ }^{184}$ which overturned a death sentence imposed for murder found to be "outrageously or wantonly vile" under the state statute. Justice Stewart wrote the plurality opinion, joined by Justices Powell, Stevens, and Blackmun. ${ }^{185}$ Stewart held that previous decisions by the Georgia Supreme Court had given sufficient content to this apparently open-ended statutory standard to satisfy the strictures of Gregg but that in its appellate review of the petitioner's sentence, the state supreme court had not "satisf[ied] the criteria [it had previously] laid out."186

Stewart's opinion was attacked from both sides. Justice White argued in dissent that federal courts could not as a practical matter repeatedly engage in this kind of close attention to the internal integrity of the state appellate process. White mocked the Court for appearing to assume the unwieldy "role of a finely tuned calibrator of depravity."187 From the other side, Justice Marshall asserted that no amount of appellate scrutiny, federal or state, could redeem the death penalty. "[A]ppellate courts," he said, "are incapable of guaranteeing . . objectivity and evenhandedness" in capital punishment; 188 the "lapse" by the Georgia Supreme Court was not "aberrational" but systemic. 189 Both White and Marshall may have been correct in their critiques of the plurality's approach in Godfrey. Nonetheless, that approach held considerable potential as an aspirational model for detailed federal court review of state appellate proceedings and as an indication of an intention to sustain ameliorative pressure generally in the administration of the death penalty.

In retrospect, however, this kind of closely detailed, sustained observation by the Supreme Court was itself "aberrational." Beginning in 1983, the Court turned resolutely away from this pursuit, instead appearing intent on affirming capital punishment in order to suppress "the seeds of anarchy - of self-help, vigilante justice, and lynch law"

184. 446 U.S. 420 (1980).

185. After voting to uphold all the death penalty statutes at issue in the Gregg series, Blackmun did occasionally vote to overturn death penalty impositions, though customarily without opinion. See Coker v. Georgia, 433 U.S. 584 (1977); Enmund v. Florida, 458 U.S. 782 (1982). When he spoke, it was without much enthusiasm. See Lockett v. Ohio, 438 U.S. 586, 613 (1978).

186. Godfrey, 446 U.S. at 432 (plurality opinion of Stewart, J.).

187. 446 U.S. at 456 n.6 (White, J., dissenting).

188. 446 U.S. at 439 (Marshall, J., concurring).

189. 446 U.S. at 435 (Marshall, J., concurring). 
that Justice Stewart had seen and feared in Furman. ${ }^{190}$ Although Stewart himself left the Court in 1981, his absence was not the key to a changed Court attitude. Justice O'Connor, who succeeded Stewart, has voted almost invariably to uphold death penalty impositions; but since 1983 Justice Powell has voted the same way, thus constituting a Court majority even without O'Connor's vote, to turn away from the scrutinizing enterprise that Stewart apparently charted. ${ }^{191}$ Stewart's enterprise was, moreover, ambivalent from the outset. Though its polarities remained obscure during his tenure, the distaste for public conflict always present in his jurisprudence might well have led him to join Powell in finally abandoning the scrutinizing enterprise simply because of the progressively (though incrementally) increasing controversy that inevitably accompanied that enterprise. ${ }^{192}$

The Court's overall performance since Gregg reveals an implicitly anarchic element marked by repeated fractionation even among those who constituted the majority apparently engaged in scrutinizing state death penalty practices. This internal division itself may have doomed any serious scrutinizing enterprise. To sustain this kind of endeavor - this patiently incremental, quiet but persistent gadfly role - required both a long-range clarity of vision and a tenacious will. Perhaps if the Justices had been more united, as prior Justices had been regarding racial segregation before and during the Warren era, ${ }^{193}$ the Court might have sustained this endeavor regarding the death penalty.

Perhaps, however, nothing could have saved it. It may be more likely that the unruly social and psychological forces inherent in the death penalty make it especially difficult for anyone to give sustained, openly acknowledged attention to it. It is also possible that in the years following Gregg, the death penalty dispute itself had become so visible and so visibly polarized that it had given a recognizable form

190. 408 U.S. at 308 (Stewart, J., concurring).

191. See Barefoot v. Estelle, 463 U.S. 880 (1983); Barclay v. Florida, 463 U.S. 939 (1983); Pulley v. Harris, 465 U.S. 37 (1984); Wainwright v. Witt, 469 U.S. 412 (1985); Lockhart v. McCree, 106 S. Ct. 1758 (1986).

192. This aspect of Justice Stewart's jurisprudence found clear expression in his opinion for the Court in Walker v. City of Birmingham, 388 U.S. 307, 320-21 (1967), holding that civil rights demonstrators were bound to obey an injunction notwithstanding its possible constitutional invalidity, on the ground that they were not "free to ignore all the procedures of the law and carry their battle to the streets." Justice Powell revealed a similar, perhaps even more adamant, purpose to suppress public controversy by burying the occasions for its occurrence in his separate opinion in Regents of the Univ. of Cal. v. Bakke, 438 U.S. 265, 315-20 (1978). Compare Justice Blackmun's observation regarding the distinction Powell drew between the constitutionally permissible admissions policy at Harvard and the impermissible U.C. Davis policy: "The cynical ... may say that under a program such as Harvard's one may accomplish covertly what Davis concedes it does openly." 438 U.S. at 406.

193. See notes 108-10 supra and accompanying text. 
and vocabulary to pervasive, though less distinct or distinctly acknowledged, sources of polarized conflict in our society (e.g., racial, economic, class, and gender). Whatever the explanation, the fact is that after 1983 a majority of the Justices resolutely faced in a new direction regarding the constitutional status of capital punishment. They looked away; they turned their backs on the enterprise.

\section{Phase III: DoubTS SuPPRESSED}

In April 1979, Justice Rehnquist noted his impatience at the absence of any executions since the Court's rulings in Gregg. With his customary expressive grace, Rehnquist observed, "If the holdings of our Court ... are to be anything but dead letters, capital punishment when imposed pursuant to the standards laid down in those cases is constitutional; and ... the State is entitled to carry out the death sentence."194 Six weeks later, Florida executed John Spenkelink, thus ending the national moratorium that had held since 1967.195 This one execution, however, was not enough for Justice Rehnquist. In 1981, when no one else had yet been executed, Rehnquist drew a grim account of the implications he saw:

[W] have thus reached a stalemate in the administration of federal constitutional law.... [T]he existence of the death penalty in this country is virtually an illusion. ...

I do not think that this Court can continue to evade some responsibility for this mockery of our criminal justice system. . . .

...

... I believe we have in our judicial decisions focused so much on controlling the government that we have lost sight of the equally important objective of enabling the government to control the governed. When our systems of administering criminal justice cannot provide security to our people in the streets or in their homes, we are rapidly approaching the state of savagery. ... In Atlanta, we cannot protect our small children at play. In the Nation's Capital, law enforcement authorities cannot protect the lives of employees of this very Court who live four blocks from the building in which we sit and deliberate the constitutionality of capital punishment. ${ }^{196}$

As if to apply the maxim that desperate circumstances demand desperate expedients, Rehnquist offered a solution to the problem as he saw it. The Supreme Court should act decisively to end delays in executions by granting certiorari in every capital case coming from the state courts. The happy consequence, he stated, would be conclusively

194. Evans v. Bennett, 440 U.S. 1301, 1303 (1979).

195. See text at notes 322-25 infra.

196. Coleman v. Balkcom, 451 U.S. 949, 957-58, 962 (1981) (Rehnquist, J., dissenting from denial of certiorari). 
to dispose of "all issues of fact or law" regarding federal constitutional claims; "the jurisdiction of the federal courts . . . would be at an end, and ... petitioner's sentence ... would presumably be carried out."197 This proposal was not greeted enthusiastically by Rehnquist's colleagues. As Justice Stevens observed, a further and unhappy consequence would be to "consume over half of this Court's argument calendar," based on the number of certiorari petitions in capital cases filed during the preceding ten months. ${ }^{198}$

In making this proposal, Justice Rehnquist appeared to join ranks with Justices Brennan and Marshall in their persistent dissents from denial of certiorari in capital cases. ${ }^{199}$ Like them, Rehnquist might have argued that review of all capital cases would not unduly tax the Court's resources if the Court correctly approached the merits of the cases. Of course, Rehnquist's approach would bring results diametrically opposed to those espoused by Brennan and Marshall; but he too, it seems, had a universal solvent for disposing of death penalty cases. As Justice Stevens acidly observed, "those questions have not been difficult for three Members of the Court," noting that "Justice Brennan and Justice Marshall have invariably voted to set aside the death penalty and, if my memory serves me correctly, Justice Rehnquist has invariably voted to uphold the death penalty."200

Rehnquist did not persist in pressing his proposal. If he had done so, he might have converted the traditional "rule of four" for certiorari grants to a rule of one in capital cases, since three Justices would invariably be voting to review all capital cases. If so, however, might the other Justices have discounted these automatic votes and perhaps adopted a new rule of seven in capital cases with yet another systemic distortion ascribable to the jurisprudence of the death penalty? The question was never tested.

Rehnquist had been the most strident spokesman on the Court for the view that persistent challenges to the constitutionality of the death penalty undermined the rule of law, or at least the ability of "the government to control the governed."201 He had also been the most fervent advocate for eschewing any special constitutional scrutiny of death cases. But others on the Court shared his concern and a majority ultimately embraced the result he sought in response to that concern. None of the other Justices ever accepted Rehnquist's proposal to

197. 451 U.S. at 963-64.

198. 451 U.S. at 950 (Stevens, J., concurring in denial of certiorari).

199. See notes 133-35 supra and accompanying text.

200. Balkcom, 451 U.S. at 951 \& n.2 (Stevens, J., concurring in denial of certiorari).

201. 451 U.S. at 962 (Rehnquist, J., dissenting from denial of certiorari). 
grant certiorari in every capital case, but a majority soon undertook to close off most avenues of federal constitutional relief by other means.

A variety of expedients were adopted to this end. One was to encourage swift dispositions of federal habeas review. In 1983, the Court addressed substantive standards for summary dismissals of appeals from habeas denials. Courts of appeals, the Court held, could summarily dismiss not only patently "frivolous" appeals but also those cases where the claimant could not "make a 'substantial showing of the denial of [a] federal right." "202 Moreover, even where summary dismissal was unwarranted, the Court invited the adoption of procedures to provide for expedited argument on the merits in capital cases at the same time that the appellate court considered the customarily separate and preliminary question of whether to grant a stay of execution pending appeal. 203

Another route was to encourage the states themselves to treat capital cases with less careful (and thus less time-consuming) attention. To this end, in 1983 the Court permitted state appellate courts to disregard even admitted errors in death sentence proceedings on the basis of an expansive construction of the "harmless error" rule. ${ }^{204}$ In 1984, the Court clearly informed state appellate courts that they were not required to assess, by a so-called "proportionality review," the comparability of any particular death sentence to others imposed in the state. ${ }^{205}$ A Court majority had already approved a death penalty statute without provision for such review in the Texas case decided in 1976 as part of the Gregg series, ${ }^{206}$ but the other dispositive opinions in the Gregg series spoke as if proportionality review was an important and therefore required safeguard. ${ }^{207}$ In 1984, however, there could be no doubt about the Court's intention to remit proportionality review. Justice White, writing for the Court, plainly announced this result; 208 for some thirty other states already committed to such review (perhaps based on a cautious reading of the Court's prior decisions in Gregg and Furman), this was a virtual invitation to abandon the enterprise. ${ }^{209}$

In 1985, the Court returned to the beginning - to the question that in 1968 had initiated its sustained scrutiny of the death penalty,

202. Barefoot v. Estelle, 463 U.S. 880,893 (1983) (quoting Stewart v. Beto, 454 F.2d 268, 270 n.2 (5th Cir. 1971), cert. denied, 406 U.S. 925 (1972)).

203. 463 U.S. $880,894-95$.

204. Barclay v. Florida, 463 U.S. 939, 990 (1983).

205. Pulley v. Harris, 465 U.S. 37 (1984).

206. Jurek v. Texas, 428 U.S. 262 (1976).

207. See notes 154-73 supra and accompanying text.

208. Pulley, 465 U.S. at 50.

209. See 465 U.S. at 71 (Brennan, J., dissenting). 
the question of excluding jurors opposed to capital punishment. The Court's decision in Wainwright $v$. Witt ${ }^{210}$ epitomizes the current phase of its death penalty jurisprudence. Witt announced a new substantive rule for juror exclusions to "modify the test stated in Witherspoon."211 The Court's "modification" reiterated part of the original Witherspoon formula: a juror may be excluded if his views on capital punishment would "prevent or substantially impair the performance of his duties as a juror in accordance with his instructions and his oath." 212 But Witt explicitly jettisoned Witherspoon's further requirement that excludable jurors make "unmistakably clear . . . that they would automatically vote against the imposition of capital punishment."213

Beyond this substantive change, and even more significantly, the Court altered the procedural framework in which the Witherspoon standard had been applied. Henceforth, the Court said, "deference must be paid to the trial judge who sees and hears the juror";214 in federal habeas reviews, the state judge's exclusion of any juror carried a "presumption of correctness."215 Federal appeals courts had previously refused to employ such presumption and had instead independently examined the voir dire transcript to ensure observance of the Witherspoon standard. This basis for review had in recent years been a fecund source for post-trial reversals, particularly in federal proceedings. ${ }^{216}$

Witt promised to close off this route by positing a substantive standard that invited state trial judges to exclude more jurors than before and by insulating any such exclusion from federal constitutional review. ("Despite ... lack of clarity in the printed record, ... there will be situations where the trial judge is left with the definite impression that a prospective juror would be unable to faithfully and impartially apply the law."217) In theory, of course, the "presumption of correctness" could be overcome; but the possibility in practice would depend

210. 469 U.S. 412 (1985).

211. 469 U.S. at 424 n.5.

212. 469 U.S. at 424 (quoting Adams v. Texas, 448 U.S. 38, 45 (1980)).

213. Witherspoon v. Illinois, 391 U.S. 510, 522 n.21 (1968); see 469 U.S. at 422, 424-25.

214. 469 U.S. at 426.

215. 469 U.S. at 426 (citing 28 U.S.C. § 2254(d) (1982)).

216. See, e.g., Darden v. Wainwright, 725 F.2d 1526 (11th Cir. 1984); Davis v. Zant, 721 F.2d 1478 (11th Cir. 1983); Spencer v. Zant, 715 F.2d 1562 (11th Cir. 1983); Hance v. Zant, 696 F.2d 940 (11th Cir. 1983); O'Bryan v. Estelle, 691 F.2d 706 (5th Cir. 1982); Burns v. Estelle, 626 F.2d 396 (5th Cir. 1980); Herring v. State, 446 So. 2d 1049 (Fla.), cert. denied, 469 U.S. 989 (1984); People v. Velasquez, 28 Cal. 3d 461, 622 P.2d 952, 171 Cal. Rptr. 507 (1980); People v. Gaines, 88 Ill. 2d 342, 430 N.E.2d 1046 (1981), cert. denied, 456 U.S. 1001 (1982); State v. Mercer, 618 S.W.2d 1 (Mo.), cert. denied, 454 U.S. 933 (1981). See generally Schnapper, Taking Witherspoon Seriously: The Search for Death-Qualified Jurors, 62 TEXAS L. REv. 977 (1984).

217. 469 U.S. at $425-26$. The breadth of this deference is suggested by the Court's ruling in 
on whether the voir dire transcript showed with "unmistakable clarity" that the trial judge had erred. The construction of such transcript would depend in turn on the skill and tenacity of the defense attorney. But, of course, the typical attorney for an indigent defendant, who is most likely to attract a death sentence, is least likely to have such capacities. 218 In practice, the "presumption of correctness" is likely to be irrebuttable.

In Witt, the Supreme Court came full circle. Not only did it effectively dismantle Witherspoon, it accomplished this end by moving back to the ultimate criterion, the conclusive presumption of regularity, that Justice Harlan had invoked in McGautha to pretermit any constitutional scrutiny of death penalty statutes. For Harlan, the state death penalty statute was a self-validating instrument in constitutional law. "The States," he said, "are entitled to assume that jurors . . . will act with due regard for the consequences of their decision . . .."219 Federal courts, that is, are obliged to assume that states have embraced this assumption of fair conduct by the simple fact that the states have entrusted the sentencing task to jurors. In Witt, the Court effectively invoked this same assumption to screen the actions of state trial judges from federal constitutional review.

This evisceration of Witherspoon was carried further in 1986 by Lockhart v. McCree. ${ }^{220}$ The specific question at issue was whether the exclusion of jurors unwilling to impose a death sentence created a jury panel that was unduly biased against criminal defendants in considering guilt or innocence. The question had been raised in Witherspoon but Justice Stewart, for the Court, held that the supporting data presented was "too tentative and fragmentary"221 to establish the claimed bias. He clearly implied, however, that if such bias could be shown, then some remedial consequence must follow. ${ }^{222}$ (The most plausible remedy would be to require the impanelling of two separate juries, one for guilt and the other for sentencing, in every capital

Darden v. Wainwright, 477 U.S. 168 (1986), affirming the Eleventh Circuit's decision, following a remand in light of Witt, to vacate its prior finding of a Witherspoon juror exclusion violation.

218. See Goodpaster, The Trial for Life: Effective Assistance of Counsel in Death Penalty Cases, 58 N.Y.U. L. REv. 299, 300-05 (1983). The Court has, moreover, recently made clear that it will not carefully scrutinize defense attorney conduct to assure effective representation in death penalty cases. Strickland v. Washington, 466 U.S. 668, 689 (1984) ("'j]udicial scrutiny of counsel's performance must be highly deferential").

219. McGautha v. California, 402 U.S. 183, 207-08 (1971).

220. 106 S. Ct. 1758 (1986).

221. Witherspoon, 391 U.S. at 517.

222. Even Justice White, in his dissent from the Court's limitation of state authority to exclude death penalty opponents from sentencing, acknowledged that demonstrated convictionproneness of a death-qualified jury would concern him. See 391 U.S. at 541 n.1. 
case. ${ }^{223}$ ) The issue returned nineteen years later in Lockhart. The Court ruled this time that the supporting data was no more convincing than before; but as if to forestall any further efforts at data collection or litigative advocacy, the Court held that even if "death-qualified juries" were demonstrably more "conviction-prone" than others, this finding would have no constitutional significance.

The Court's opinion, by Justice Rehnquist, threw up a potpourri of arguments to reach this result. Some of the arguments were patently illogical. For example, Rehnquist argued that since chance selection of jurors might also produce a conviction-prone panel, purposeful state selection for this same characteristic raised no special concern, and that to forbid the purposeful state exclusion of acquittal-prone jurors implied that the state must be required to insure ideological balance on all jury panels, including equal representation of "Democrats and Republicans, young persons and old persons . . . and so on."224

Other arguments simply lacked weight. The Court's assumption of conviction-proneness necessarily implied that the constitutional rights of capital defendants were directly impaired. Even if the presumption of innocence in criminal proceedings was disregarded here (as the Court silently suggested), the Court did at least openly acknowledge the existence of a right to an impartial jury. ${ }^{225}$ From this predicate, the Court was obliged to find some countervailing state interest that would adequately justify its creation of conviction-prone juries and consequent derogation from the impartiality guarantee. The state could sensibly maintain that jurors unwilling to impose a death penalty should be barred from sentencing deliberations, but as the Court conceded - all such jurors would not automatically vote against guilt to shield any defendant from the possibility of death. ${ }^{226}$

A two-jury scheme for capital cases, if practicable, thus would appear necessary to honor the defendant's constitutionally sanctioned interest in securing an impartial adjudication of guilt. But Justice Rehnquist hardly bothered to consider the substantiality of any state objections to the implementation of such a scheme. He merely conclusively asserted that states preferred a unitary jury in capital cases because "the two questions [of guilt and punishment] are necessarily

223. The Eighth Circuit had, however, suggested that some other remedies might suffice, such as selecting alternate jurors to sit through the initial guilt trial or assigning full sentencing authority to the judge, perhaps aided by an advisory jury. See Grigsby v. Mabry, 758 F.2d 226, 243 (8th Cir. 1985), revd. sub nom. Lockhart v. McCree, 106 S. Ct. 1758 (1986).

224. $106 \mathrm{~S}$. Ct. at 1767.

225. $106 \mathrm{~S}$. Ct. at 1766-67.

226. $106 \mathrm{~S}$. Ct. at 1764. 
interwoven"227 and - straining even further toward makeweight "in at least some capital cases, the defendant might benefit at the sentencing phase of the trial from the jury's 'residual doubts' about the evidence presented at the guilt phase."228 Justice Marshall opened his dissent in this case with the observation that the Court's opinion displayed "a glib nonchalance ill-suited to the gravity of the issue presented and the power of respondent's claims."229 The entire tenor of the Court's opinion indeed conveys an impatient dismissiveness, as if the claims raised were not simply unjustified but hardly worthy of any effort at convincing refutation.

One further aspect of the Court's opinion reinforces this impression and starkly marks the distance traveled from the time Witherspoon was decided. In several places, Justice Rehnquist virtually characterized jurors who are excluded from capital cases as bad citizens: They are not "willing to temporarily set aside their own beliefs in deference to the rule of law," nor "conscientiously obey the law with respect to one of the issues in a capital case."230 Accordingly, Rehnquist concluded, it "hardly can be said to create an "appearance of unfairness" "231 to exclude such unworthies from civic participation on jury panels in death penalty cases. This characterization in Lockhart of jurors conscientiously opposed to the death penalty is very different from Justice Stewart's portrayal for the Court in Witherspoon: the scrupled citizen "who harbor[s] doubts about the wisdom of capital punishment" 232 because he is moved by a "shuddering recognition of a kinship" 233 even with a condemned criminal, and yet might "nonetheless subordinate his personal views to what he perceived to be his duty to abide by his oath as a juror."234 There is a respectful, even admiring, tone to this portrayal in Witherspoon that buttresses its wish to include this juror in communal deliberations - an attitude that is wholly absent in Lockhart and wholly inconsistent with its intention to exclude this doubting, dissentient juror.

Lockhart thus reveals both the central characteristic of this latest phase in the Supreme Court's death penalty jurisprudence and its basic difference from the initial phase in Witherspoon: the Court is now in-

227. 106 S. Ct. at 1768 (quoting Rector v. State, 280 Ark. 385, 395, 659 S.W.2d 168, 173 (1983)).

228. $106 \mathrm{~S}$. Ct. at 1769.

229. $106 \mathrm{~S}$. Ct. at 1771 (Marshall, J., dissenting).

230. $106 \mathrm{~S}$. Ct. at 1766.

231. $106 \mathrm{~S}$. Ct. at 1766.

232. Witherspoon, 391 U.S. at 520.

233. 391 U.S. at 520 n.17 (quoting A. Koestler, Reflections ON HANGING 167 (1956)).

234. 391 U.S. at 515 n.7. 
tent on suppressing rather than exploring doubts about capital punishment. Lockhart might be read to hold that the doubts raised in the initial phase have now been considered and resolved, but its dismissive tone more clearly and insistently conveys that the Court is simply unwilling to give serious attention to any doubts, no matter how wellfounded. The intense deliberative process launched by Witherspoon is thus not so much ended as abandoned.

Lockhart signifies the end of this process in another less obvious but ultimately more telling way. Before Justice Rehnquist "assume[d] for purposes of [the Court's] . . o opinion"235 that conviction-proneness of "death-qualified" juries had been proven, he reviewed (and dismissed) some of the evidence for this proposition but omitted any discussion of the most probative supporting data. Rehnquist restricted his attention to the social science experiments that had been put in evidence before the district judge in Lockhart. He found that only six studies "even purported to measure"236 conviction-proneness among jurors, that three of these had been in evidence in Witherspoon and were no less "tentative and fragmentary" now than the Court had found then, 237 and that the three "new" studies were of dubious value because they were based on jury simulations rather than an investigation of "the behavior of actual jurors."238 There is a small irony in this last observation, since social science investigators generally have been barred from studying actual jurors by court rules designed to protect the confidentiality of jury proceedings. ${ }^{239}$ But there is another source of data that Rehnquist did not acknowledge, much less refute: the extensive experience of trial judges and attorneys since Witherspoon had been decided.

The trial judge in Lockhart was quite explicit in finding that the social science experiments were not the sole or even primary evidence on which he rested his judgment that death-qualified jurors were inappropriately conviction-prone. These experiments, Chief Judge Eisele held, were convincing because they were congruent with the "common sense" reflections of experienced legal system participants. The studies, he said, only proved what trial lawyers and judges knew all along.

[T]he "gut" judgments of trial lawyers and judges as to the fairness of voir dire procedures, and as to the necessity therefor, are not just intui-

235. Lockhart, $106 \mathrm{~S}$. Ct. at 1764.

236. $106 \mathrm{~S}$. Ct. at 1762.

237. $106 \mathrm{~S}$. Ct. at 1763.

238. $106 \mathrm{~S}$. Ct. at 1763.

239. See 106 S. Ct. at 1773 (Marshall, J., dissenting) (citing Grigsby v. Mabry, 758 F.2d 226, 237 (8th Cir. 1985), revd. sub nom. Lockhart v. McCree, 106 S. Ct. 1758 (1986)). 
tive generalizations about human experience but also represent a reflection of the training and experience of such persons over time in the courtrooms of this nation. After one has conducted or observed hundreds of voir dire examinations and has read endless pages of transcripts of the death qualification process he should be able to form a judgment as to whether such procedures are fair or whether they tend to prejudice one or the other party. . . . This is simply: law work.

Here the fireside inductions clearly support the contentions of petitioners. If asked, "Does the removal of all prospective jurors with adamant objections to the death penalty result in a jury more prone to convict?" Trial lawyers and judges will answer, "yes, of course." If asked, "Does the usual process of death qualification itself, as observed time and again, prejudice the defendant?["] The answer, "yes, clearly." 240

Justice Rehnquist's failure even to mention this basis for the trial court's conclusion not only bowdlerizes the conclusion, but also ignores the most important aspect of the inquiry initiated by Witherspoon.

Witherspoon was no more an invitation for social scientists to investigate the fairness and rationality of the jury selection process in capital cases than the Supreme Court's decisions in the graduate school race segregation cases ${ }^{241}$ were simply or primarily an invitation for Kenneth Clark to perform his white doll/black doll study. ${ }^{242}$ Witherspoon, like the early segregation cases, was a signal that the Supreme Court was troubled about the constitutional legitimacy of a long-standing, well-entrenched social practice, and that the Court intended to launch a self-conscious, intensive scrutiny of the practice through many forums - litigation, legislation, media, and general public discourse, as well as academia. Nineteen years later, when it reexamined the specific question posed but not answered in Witherspoon, the Supreme Court acted as if the inquiry had never been launched. It was of course not bound to accept Judge Eisele's finding - in effect, his testimony - regarding the " 'gut' judgments of trial lawyers and judges" 243 based on their capital jury selection experience. But the Court was obliged to acknowledge the existence and possible relevance of that experience, of the extended process of self-conscious judicial

240. Grigsby v. Mabry, 569 F. Supp. 1273, 1322 (E.D. Ark. 1983), affd., 758 F.2d 226 (8th Cir. 1985) (en banc), revd. sub nom. Lockhart v. McCree, 106 S. Ct. 1758 (1986).

241. Sweatt v. Painter, 339 U.S. 629 (1950); Sipuel v. Board of Regents, 332 U.S. 631 (1948); Missouri ex rel. Gaines v. Canada, 305 U.S. 337 (1938).

242. See K. Clark, Effect of Prejudice and Discrimination on Personality DeVELOPMENT (Midcentury White House Conference on Children and Youth, 1950), cited in Brown v. Board of Educ., 347 U.S. 483, 494 n.11 (1954).

243. 569 F. Supp. at 1322. 
inquiry and reflection that had been effectively mandated by Witherspoon.

It is least surprising that Justice Rehnquist of all members of the Court should disregard this experience because he, more adamantly and explicitly than any of the others, has believed that the extended process of judicial inquiry into capital punishment since Witherspoon has itself been a mistake, a process with needlessly and destructively high social costs. Rehnquist has most clearly revealed this conviction in his complaints about the execution delays that have attended judicial deliberations, as in this 1981 observation:

What troubles me is that this Court, by constantly tinkering with the principles laid down in the five death penalty cases decided in 1976, together with the natural reluctance of state and federal habeas judges to rule against an inmate on death row, has made it virtually impossible for States to enforce with reasonable promptness their constitutionally valid capital punishment statutes. When society promises to punish by death ... , and then the courts fail to do so, the courts not only lessen the deterrent effect of the threat of capital punishment, they undermine the integrity of the entire criminal justice system. ${ }^{244}$

The Court itself, he concluded, bore "some responsibility for this mockery of our criminal justice system" 245 which threatened to reduce society to a "state of savagery."246

Justice Stevens replied that the state legislative responses to Furman had "generated a number of novel constitutional questions ... [which were] sufficiently important and difficult to justify the delays associated" with judicial review. ${ }^{247}$ But Rehnquist was not convinced. The litigated questions were not important or difficult by his lights; they were bogus, manufactured by lawyers engaging in "tactic[s] unworthy of our profession," 248 who filed endless petitions until some judge somewhere would "create or assume doubts where in fact there are none."249

Though defense attorneys might indeed be motivated to act as Rehnquist charged, it is more difficult to fathom the reasons for judicial collaboration or gullibility. Rehnquist, however, offered a systemic explanation: "Given so many bites at the apple, the odds favor petitioner finding some court willing to vacate his death sentence

244. Coleman v. Balkcom, 451 U.S. 949, 959 (1981) (Rehnquist, J., dissenting from denial of certiorari). See also text at note 196 supra.

245. 451 U.S. at 958.

246. 451 U.S. at 962.

247. 451 U.S. at 951 (Stevens, J., concurring in denial of certiorari).

248. Evans v. Bennett, 440 U.S. 1301, 1307 (Rehnquist, Circuit Justice 1979).

249. Wainwright v. Spenkelink, 442 U.S. 901, 902 (1979) (Rehnquist, J., dissenting from denial of motion to vacate stay). 
...."250 But why would the odds favor the petitioner in this process? What was "the apple" that Rehnquist had in mind: The apple of discord? Of knowledge?

In a 1983 opinion, Justice Marshall provided documentation for Rehnquist's statistical claim, though not necessarily for his explanation of those statistics. Marshall cited the success of habeas petitions in federal courts of appeals:

[E]xperience shows that prisoners on death row have succeeded in an extraordinary number of their appeals. Of the 34 capital cases decided on the merits by Courts of Appeals since 1976 in which a prisoner appealed from the denial of habeas relief, the prisoner has prevailed in no fewer than 23 cases, or approximately $70 \%$ of the time. In the Fifth Circuit, of the 21 capital cases in which the prisoner was the appellant, the prisoner has prevailed in 15 cases. This record establishes beyond any doubt that a very large proportion of federal habeas corpus appeals by prisoners on death row are meritorious, even though they present claims that have been unsuccessful in the state courts, that this Court in its discretion has decided not to review on certiorari, and that a federal district judge has rejected. ${ }^{251}$

Marshall's statistics addressed only the last stages of the review process. Surveys of the earlier stages, including direct appeals in state tribunals, have indicated a similarly high reversal rate for death sentences. For example, the Florida Supreme Court reviewed 247 death sentence cases from 1972, after Furman, until March 1984; of these, 116 or forty-seven percent were set aside. ${ }^{252}$ Overall, according to a 1982 study, from sixty to seventy-five percent of defendants sentenced to death obtain reversals at some point in their appeals, ${ }_{2}^{253}$ this is roughly ten times the reversal rate in federal criminal appeals and almost one hundred times the reversal rate for general felony convictions in California. 254

This is a staggering number of reversals. There are of course a multitude of particular reasons that might individually explain the various reversals. But I would say, contrary to Justice Rehnquist's claim, that the odds in all these tribunals work against the petitioners:

250. Balkcom, 451 U.S. at 957 (Rehnquist, J., dissenting from denial of certiorari).

251. Barefoot v. Estelle, 463 U.S. 880, 915 (1983) (Marshall, J., dissenting) (footnotes omitted). See also Wright \& Miller, In Your Court: State Judicial Federalism in Capital Cases, 18 URB. LAW. 659, 669-70 (1986).

252. M. Vandiver \& M. Radelet, Post-Furman Death Sentences in Florida (Sept. 20, 1984) (unpublished manuscript) (available from the Capital Punishment Project, Sociology Department, University of Florida). A 1985 study found a similar proportion of death sentence reversals among the states generally. NAACP Legal Defense Fund, Inc., Death Row, U.S.A. (Oct. 1985) (unpublished manuscript).

253. Greenberg, Capital Punishment as a System, 91 YALE L.J. 908, 917-18 (1982).

254. Id. at 918. 
they are all murderers; ${ }^{255}$ resources for their appellate representation are stretched thin; and public forbearance for them as individuals and for the review process itself is frayed. Notwithstanding these heavy odds, as I assess them, death sentences during these times were reversed in one tribunal or another in somewhere between half and three-quarters of the cases.

These results do indeed threaten, as Justice Rehnquist charged, to make a "mockery of our criminal justice system"256 and to undermine "the integrity of the entire . . system"257 - but not for the reasons that he proffered, not because shyster lawyers were so successful in tricking gullible federal and state judges. If we entertain the possibility that these various appellate and collateral review reversals were meritorious, it is difficult to avoid the suspicion that our criminal justice system impeaches its own integrity by producing reversible errors in between half and three-quarters of its cases. These are, moreover, not trivial cases; they involve the potential infliction of death where one might assume - front-line dispensing officers would be more careful in their conduct than in their ordinary dispensations. If serious cases subjected to correspondingly serious review are mishandled in so many instances, what must we conclude about the possibilities of undiscovered error, undetected impropriety, of official misbehavior in the less serious, the everyday proceedings in the criminal justice system?258 The Supreme Court must indeed bear "some responsibility for this mockery of our criminal justice system," as Justice Rehnquist charged $^{259}$ - but only because these results have emerged from the Court's own intense scrutiny of the workings of the capital punishment system.

An additional motive for ending this judicial scrutiny thus emerges, a motive different from Rehnquist's claim that only bogus errors have been found. This added motive can be glimpsed between the lines of two observations made, almost a decade apart, by Justice White. In his 1976 opinion in Gregg, White said:

Petitioner's argument that there is an unconstitutional amount of discretion in the system ... seems to be in final analysis an indictment of our entire system of criminal justice. Petitioner has argued, in effect, that no matter how effective the death penalty may be as a punishment, gov-

255. So the Court has required in Coker v. Georgia, 433 U.S. 584 (1977).

256. Balkcom, 451 U.S. at 958 (Rehnquist, J., dissenting from denial of certiorari).

257. 451 U.S. at 959.

258. Cf. Kamisar, Equal Justice in the Gatehouses and Mansions of American Criminal Procedure: From Powell to Gideon, From Escobedo to . . . in CRIMINAL JUSTICE IN OUR TIME 1 (A. Howard ed. 1965) (discussing police interrogation of criminal suspects).

259. 451 U.S. at 958 (Rehnquist, J., dissenting from denial of certiorari). 
ernment, created and run as it must be by humans, is inevitably incompetent to administer it. This cannot be accepted as a proposition of constitutional law. ${ }^{260}$

In his 1984 opinion for the Court, dispensing with any requirement for state appellate proportionality review, White observed:

Any capital sentencing scheme may occasionally produce aberrational outcomes. Such inconsistencies are a far cry from the major systemic defects identified in Furman. As we have acknowledged in the past, "there can be "no perfect procedure for deciding in which cases governmental authority should be used to impose death." "261

On their face, these two observations seem consistent; in both instances, White eschews perfection as a standard for measuring state death penalty statutes. There is, however, an unacknowledged tension between them. The absence of perfection may mean an occasional lapse from the norm or it may mean routine, gross disregard for it. In his 1984 opinion, White asserted that the absence of perfection in the state statute was only an "occasional . . . aberration," a "far cry from the major systemic defects" that had previously characterized capital punishment. ${ }^{262}$ But how could White know this as fact? In the decision itself, he eliminated any requirement that states use a reviewing mechanism, appellate proportionality review, that could reveal whether apparent imperfections were occasional or systemic. ${ }^{263}$

From White's reasoning in Gregg - that an argument refuted itself if it led "in final analysis to an indictment of our entire system of criminal justice"264 — it was a short step to conclude that any judicial inquiry leading to this result must be conclusively, irrebuttably rejected. This is the position that a majority of the Justices have now embraced. It is the inner, though unacknowledged, logic that joins together all of the major death penalty decisions of the Supreme Court in this latest phase of its jurisprudence: dispense with state proportionality review, ${ }^{265}$ speed up federal collateral review processes, ${ }^{266}$ ex-

260. Gregg v. Georgia, 428 U.S. 153, 225-26 (1976) (White, J., concurring).

261. Pulley v. Harris, 465 U.S. 37, 54 (1984) (quoting Zant v. Stephens, 462 U.S. 862, 884 (1983) (quoting Lockett v. Ohio, 438 U.S. 586, 605 (1978) (plurality opinion))).

262. 465 U.S. at 54.

263. See generally Barnett, Some Distribution Patterns for the Georgia Death Sentence, 18 U.C. DAvis L. REv. 1327 (1985) (empirical study of death penalty application); Baldus, Woodworth \& Pulaski, Monitoring and Evaluating Contemporary Death Sentencing Systems: Lessons from Georgia, 18 U.C. DAVIS L. REV. 1375 (1985) (discussing usefulness of properly designed appellate proportionality review in capital cases).

264. Gregg, 428 U.S. at 226.

265. See Pulley v. Harris, 465 U.S. 37 (1984).

266. See Barefoot v. Estelle, 463 U.S. 880 (1983). See also Note, The Rush to Execution: Successive Habeas Corpus Petitions in Capital Cases, 95 YALE L.J. 371 (1985) (authored by John B. Morris, Jr.). 
pand the definition of "harmless error,"267 and curtail review of juror exclusions. ${ }^{268}$ Just as the Court in Witt openly decided to permit more extensive culling of jurors with doubts about the death penalty, it also decided to remove opportunities for others, including federal judges, to doubt the fairness of capital punishment or, by necessary extension, the integrity of the criminal justice system.

The Court's 1987 decision in McCleskey v. Kemp ${ }^{269}$ represents the capstone of this effort to suppress all doubts. The complainants in McCleskey claimed to have documented the persistence of extensive racial bias in the administration of the death penalty. If the Court had validated this claim, if it had acknowledged that such racism persists notwithstanding almost a generation's effort at judicially sponsored reform, the Court would have virtually pronounced (in Justice White's words) "an indictment" 270 that would tend (in Justice Rehnquist's words) to "undermine the integrity of the entire criminal justice system."271 Justice Powell, in writing the Court's opinion in McCleskey, admitted as much: "McCleskey's claim, taken to its logical conclusion, throws into serious question the principles that underlie our entire criminal justice system. ... [I]f we accepted [his] . . claim that racial bias has impermissibly tainted the capital sentencing decision, we could soon be faced with similar claims as to other types of penalty."272 Little wonder, then, with the stakes so high, that the Court majority refused to give credence to this claim.

From its very beginning, the charge of racism in the administration of the death penalty was often the text and always the subtext of the abolitionist litigative campaign. ${ }^{273}$ Justice Marshall in Furman partly rested the case for abolition on this ground.274 At that time, however, it was plausible to argue, as Justice Stewart did, that "racial discrimination ha[d] not been proved" by suitably rigorous statistical criteria.275 Following Furman, state prosecutors had a strong motive to eliminate any appearance of racism by adjusting their administrative

267. See Zant v. Stephens, 462 U.S. 862 (1983); Barclay v. Florida, 463 U.S. 939 (1983).

268. See Wainwright v. Witt, 469 U.S. 412 (1985).

269. 107 S. Ct. 1756 (1987).

270. Gregg, 428 U.S. at 226.

271. Balkcom, 451 U.S. at 959 (Rehnquist, J., dissenting from denial of certiorari).

272. $107 \mathrm{~S}$. Ct. at 1779.

273. See M. MELTSNer, supra note 2, at 73-105.

274. Furman, 408 U.S. at 364-66 (Marshall, J., concurring). Justice Brennan did not mention race discrimination in his Furman opinion, but the extent to which his expressed concern in Furman about "arbitrary" inflictions, 408 U.S. at 295 (Brennan, J., concurring), referred implicitly to racial bias was made explicit in his subsequent dissenting opinion in Pulley v. Harris, 465 U.S. at 65 (Brennan, J., dissenting).

275. Furman, 408 U.S. at 310 (Stewart, J., concurring). 
practices to assure that black faces were not disproportionately evident in the capital docks or on death rows. Recent studies indicate that the racial composition of these places did indeed change after Furman. ${ }^{276}$

The possibility that racism persisted, though in less blatant form, in the administration of capital punishment was pursued by sophisticated, intensive empirical investigation supported by generous foundation funding 277 - all galvanized by the apparent promise in the welter of Furman opinions that rigorously demonstrated racism would seal the case against capital punishment. These studies found continued racial bias in the disproportionate rate of death sentences imposed for murders where whites were victims and where blacks killed whites as compared to same-race murderers or where whites killed blacks. ${ }^{278}$

In 1983, this new evidence was marshalled for litigative presentation in a Georgia federal district court on behalf of Warren McCleskey, a black man sentenced to death for the murder of a white policeman. The investigators testified that, using a complex regression analysis, six percent of all death sentences imposed could only be explained by the racial characteristics of the murderers and victims. ${ }^{279}$ Moreover, if the most clearly heinous crimes were excluded — involving, for example, torture or rape or multiple victims - so that only the so-called "mid-range" of killings were considered, then the disparity explicable only by this race difference rose to twenty percent. ${ }^{280}$ The district judge, however, found various statistical flaws in the investigations and held that no race discrimination was even prima facie proven. 281

In 1985, the Eleventh Circuit Court of Appeals en banc, by a nineto-three vote, affirmed this dismissal, but on a different ground. The majority held that, even if the statistical validity of the study were assumed, the results did not show wrongful race discrimination. ${ }^{282}$ In any particular defendant's case, they ruled, this statistical evidence could not demonstrate the presence of actual race bias; ${ }^{283}$ the statistics

276. See Zeisel, Race Bias in the Administration of the Death Penalty: The Florida Experience, 95 HARV. L. REV. 456 (1981).

277. See Lempert, Capital Punishment in the '80s: Reflections on the Symposium, 74 J. Cr1M. L. \& Criminology 1101,1110 (1983).

278. See Gross, Race and Death: The Judicial Evaluation of Evidence of Discrimination in Capital Sentencing, 18 U.C. DAviS L. REv. 1275, $1279-82$ (1985).

279. McCleskey v. Zant, 580 F. Supp. 338, 366 table 2 (N.D. Ga. 1984), revd. sub nom. McCleskey v. Kemp, 753 F.2d 877 (11th Cir. 1985) (en banc), affd. in part, 107 S. Ct. 1756 (1987).

280. McCleskey v. Kemp, 753 F.2d 877, 887 (11th Cir. 1985).

281. 580 F. Supp. at 379 .

282. 753 F.2d at $897-900$.

283. 753 F.2d. at 898 . 
were not and inherently could not be "direct evidence" of intentionally biased conduct by any juror, judge, or prosecutor. ${ }^{284}$ In 1987, the Supreme Court majority, with four Justices dissenting, followed the path marked by the Eleventh Circuit. The Court stated, "[W]e assume the study is valid statistically without reviewing the [contrary] factual findings of the District Court." It observed, nonetheless, that the study, even if valid, "can only demonstrate a risk that the factor of race entered into some capital sentencing decisions." 285 The study, that is, did not and could not show that racial bias actually occurred in the imposition of any death sentence, much less in any particular death sentence.

From this perspective, the only evidence that the Court was prepared to credit was the traditionally garnered testimony from and about the specific participants in specific cases - i.e., official actors' admissions of race bias under adversarial examination or others' direct testimony regarding the actors' individual motives. This position recalls the means by which litigative complaints about discrimination in voting registration were rendered ineffective by many federal courts in the days before the Voting Rights Act of 1965. ${ }^{286}$ The courts had insisted on laborious case-by-case proof of racial bias and correspondingly refused to give presumptive evidentiary weight to the wholesale absence of blacks from voter rolls. ${ }^{287}$

Justice Powell's opinion for the Court in McCleskey closely followed the dispositional format already approved in Lockhart: throwing a dust cloud around the statistical validity of the empirical studies; ${ }^{288}$ and then assuming "for purposes of this opinion" the validity of those studies but dismissing their constitutional significance. ${ }^{289}$ There were even stronger reasons in McCleskey than in Lockhart to predict that this Court would disregard the impeaching empirical evidence about the administration of the death penalty. If the Lockhart Court had given credence to the evidence of conviction-proneness among death-qualified jurors, a practical if somewhat cumbersome two-jury remedy could have been readily conceived.290 If, however, the Court had chosen to believe the evidence of persistent racial bias in

284. 753 F.2d. at 898.

285. McCleskey v. Kemp, 107 S. Ct. 1756, 1766 n.7 (1987) (emphasis in original),

286. Pub. L. No. $89-110,79$ Stat. 445 (codified as amended at 42 U.S.C. $\S \S 1971,1973$ to 1973bb-1 (1982)).

287. See South Carolina v. Katzenbach, 383 U.S. 301,313 (1966).

288. Compare Lockhart v. McCree, 106 S. Ct. 1758, 1764 (1986), with McCleskey, 107 S. Ct. at 176465 n.6.

289. Compare text at notes $235-40$ supra, with $107 \mathrm{~S}$. Ct. at 1766 n.7.

290. See notes 223 \& $227-28$ supra and accompanying text. 
McCleskey, a practicable remedy would have been more difficult to imagine. Perhaps a scheme of mandatory death sentences based solely on the character of the offense would work; this, however, has already been held unconstitutional in the Gregg series. ${ }^{291}$ Alternatively, sentencing discretion might be retained with racial bias reliably expunged if the decision were vested wholly in a judge with juries removed from any sentencing role. This, however, would invalidate the statutory regimes in almost every death penalty state. ${ }^{292}$ In any event, by acknowledging the existence of racism in the current administration of capital punishment, the Court would be obliged to launch a wholesale restructuring of the system almost as extensive as the task initiated by Furman. The current Court has shown little inclination for an unsettling enterprise of this magnitude.

More fundamentally, the current Court majority would not likely be favorably disposed toward the charge of racial bias because, as already noted, exploring this charge would validate doubts about the fairness of the entire criminal justice system. These doubts would not be trivial. Their full weight is suggested by one empirical finding that the Court in Lockhart also disregarded: not only are death-qualified jurors biased against criminal defendants, but these jurors are more likely to be white (and male) and, correspondingly, blacks (and women) are more likely to oppose the death penalty and thus to be excluded from capital juries.293 When we add this finding to the evidence gathered in McCleskey that capital juries impose the death penalty with disproportionate frequency on blacks who murder whites and infrequently in response to any murders of blacks, a grim portrait of the American criminal justice system emerges. This portrait shows that law enforcement in the most serious and publicly visible cases is entrusted predominantly to groups of white men who value whites' lives more than blacks', and thus they take special vengeance on blacks who murder whites and are much less concerned about the murder of blacks. Indeed, its low valuation of blacks coupled with its special arousal when blacks murder whites suggests a law enforcement regime particularly concerned with the containment of blacks, a regime that acts as if our society were gripped by fears about, and prepared to take preemptive strikes against, an explosion of race warfare.

291. Woodson v. North Carolina, 428 U.S. 280 (1976); Roberts v. Louisiana, 428 U.S. 325 (1976).

292. See Spaziano v. Florida, 468 U.S. 447,464 (1984) (validating the judge's exclusive sentencing authority in Florida notwithstanding contrary rule in almost all other states).

293. See Grigsby v. Mabry, 569 F. Supp. 1273, 1293-94 (E.D. Ark. 1983), affd., 758 F.2d 226 (8th Cir. 1985) (en banc), revd. sub nom. Lockhart v. McCree, 106 S. Ct. 1758 (1986). 
The data in McCleskey and Lockhart do not demonstrate this; they merely hint at it. ${ }^{294}$ But if this hint is taken seriously, it would impeach this society's commitment both to the ideal and to the minimal practical attainment of the rule of law. The ideal is impeached because this law enforcement regime devalues blacks as such. The practical achievement of the rule of law - if only minimally conceived as the effective maintenance of social order - is also undermined because, insofar as blacks perceive their systematic devaluation by the dominant whites, they are provoked toward overt acts of racial hostility; and insofar as whites see blacks' willingness to engage in hostile acts, their fears and repressive impulses are magnified. Thus comes a spiralling, self-fulfilling impetus toward civil warfare: the destruction of any mutual confidence, even the bare tolerance, on which civic order depends. ${ }^{295}$

Even more directly than previous death penalty cases, $\mathrm{McCleskey}$ suggests that this society is sharply divided into hostile camps. This belief (whether true or not) has been the dominant conviction among the Justices at least since Furman was decided in 1972. It was shared both by those Justices who constituted the Court majority after Gregg and by the abolitionist Justices, Brennan and Marshall. This conviction has led the Court majority to reaffirm the existence of capital punishment - initially, in Gregg, by claiming that a demonstrably fair

294. These hints are occasionally amplified in the administration of the death penaity, as when Marvin Francois stated, just before his execution, "The black race . . . is slowly dying from within and without. ... If there is such a thing as an Antichrist, it ain't one man but the whole white race." Florida Prisoner Dies for Slayings, N.Y. Times, May 30, 1985, at D23, col. 1. Similarly, when four black men murdered a white hitchhiker, they pinned on his body the note, "Warning to the oppressive state. No longer will your atrocities and brutalizing of black people be unpunished. The black man is no longer asleep. The revolution has begun..." The murderers subsequently stated, in a tape recording mailed to the victim's mother and to radio and television stations, "We are everywhere; you cannot hide from us. You have told your people to get off the streets and to stay home. That will not help, for one night they will come home and we will be there waiting." Barclay v. Florida, 463 U.S. 939, 943-44 (1983) (plurality opinion of Rehnquist, J.).

In a very different and more muted voice, Justice Marshall's position in McCleskey and immediately thereafter also conveyed bitter implications about race conflict in America. Alone among the dissenters in $\mathrm{McCleskey,} \mathrm{Marshall} \mathrm{said} \mathrm{nothing;} \mathrm{Marshall} \mathrm{did,} \mathrm{however,} \mathrm{speak} \mathrm{two}$ weeks later in a public address criticizing the "flag-waving fervor" that has accompanied the bicentennial celebration of the Constitution. The document, he said, was defective from the start:

It took a bloody civil war before the 13th Amendment could be adopted to abolish slavery, though not the consequences slavery would have for future Americans.

Thus, in this bicentennial year, we may not all participate in the festivities with flagwaving fervor. Some may more quietly commemorate the suffering, struggle and sacrifice that has triumphed over much of what was wrong with the original document, and observe the anniversary with hopes not realized and promises not fulfilled. . . .

Marshall Sounds Critical Note on Bicentennial, N.Y. Times, May 7, 1987, at A1, col. 3, B18, col. 6.

295. See Burt, supra note 96, at 480-82, 488-89; J. SHKLAR, supra note 113, at 145-47, 177. 
and rational administration of the death penalty could be achieved, and ultimately by closing off inquiry into the extent of this achievement and thus effectively, though tacitly, abandoning the enterprise. The Court majority has now tortuously worked its way back to Justice Harlan's early conclusion in McGautha, that the death penalty cannot be rationalized because its extremity necessarily reveals that Justice and Order are ultimately irreconcilable and that, since choice between these values is necessary, Order must prevail.296 (Justice Brennan aptly observed in his dissent in McCleskey that the Court's concern about the "widespread challenges" implicit in the claim of racial bias "seems to suggest a fear of too much justice.") 297

The perceived opposition between the values of Justice and Order may be rooted in, and is certainly reinforced by, the conviction that American society is itself composed of irreconcilably antagonistic individuals - whether defined in terms of competing racial, class, economic, or gender groups, or in terms of competing individuals in an inevitably hostile Malthusian universe. ${ }^{298}$ Justices Brennan and Marshall do not believe that Justice and Order are necessarily irreconcilable in principle, or that American society is inevitably divided by implacable antagonisms in practice. However, their judicial opinions, beginning with Furman, 299 suggest that they believe this American generation to be hostilely divided; and that the death penalty is both the symbol of and a persistent irritant toward the perpetuation of that hostility (that "hardened" and "embittered . . . bloodlust" among the American people that Justice Marshall first feared in Furman ${ }^{300}$ and then mournfully acknowledged in Gregg. ${ }^{301}$ ) Their prescription for ameliorating, if not ending, these hostile divisions is to abolish the death penalty; their rationale in principle, as Justice Brennan stated in McGautha, is that if Justice and Order are irreconcilable then Justice

296. See note 49 supra and accompanying text. See also Weisberg, supra note 49 , at 395:

In its own clumsy and often dishonest way, and perhaps for illegitimate reasons, the Supreme Court seems to have decided that it no longer wants to use constitutional law to foster legal formulas for regulating moral choice at the penalty trial. In this sense, ... the Court has returned to its pre-Furman view ... in which the jury gets all the information in which it can have any legitimate interest, but the law offers it no illusory guidance on the decision to kill.

297. 107 S. Ct. at 1791 (Brennan, J., dissenting).

298. Edward Johnson has identified the significance of this Malthusian view in Justice Blackmun's jurisprudence generally and specifically regarding capital punishment. E. Johnson, Life, Death, and Necessity: Justice Blackmun on Abortion and Capital Punishment 13, 44 (Mar. 4, 1985) (unpublished Yale Law School seminar paper) (citing Blackmun, Thoughts About Ethics, 24 EMORY L.J. 3 (1975)).

299. See text at notes 126-36 supra.

300. 408 U.S. at 370 n.163 (Marshall, J., concurring).

301. 428 U.S. at 232 (Marshall, J., dissenting). 
must prevail. ${ }^{302}$

I am skeptical about the practical efficacy of this prescription, but I am more concerned with their principled rationale. I believe that, consistent with their constitutional judicial role, none of the Justices was entitled to act on the assumption that Justice and Order are in principle irreconcilable. The bedrock proposition - or, one might more accurately say, the hopeful assumption - of our constitutional order was that Justice and Order could be reconciled or at least tolerably accommodated. The document does not so much proclaim this proposition, this faith, in haec verba (though the preamble's juxtaposed intention to "establish Justice . . . [and] insure domestic Tranquility"303 comes close). It is rather that the Founders selfconsciously intended to establish a mutually agreed enterprise. Any polity that claims to deserve the mutual allegiance of its members must rest on the assumption that Order and Justice are not irreconcilable goals; for otherwise the polity would be grounded merely on coercive force, on the dominance of some and unwilling submission of others, rather than on a mutually acknowledged, shared mission. ${ }^{304}$

Judges are obliged not to abandon but to promote the reconciliation of these values, not merely by espousing abstract preachments but by actively working toward reconciliation. This judicial work cannot be performed by sweeping pronouncements, by wholesale as it were. It can only be accomplished by repeated, patient, incremental attempts to replace the adamant rhetoric of polarized disputants with a reasoned discourse, appealing to the possible existence of mutual allegiances transcending the immediate dispute. ${ }^{305}$

Failure to understand and to act on this role is the central error of those judges who have turned away from insistence on reasoned justification for the application of capital punishment - either openly disavowing the effort, as Justice Harlan did for the Court in McGautha, or covertly though unmistakably abandoning it, as the current Court

302. 402 U.S. at 249-50 (Brennan, J., dissenting).

303. U.S. CoNST. preamble.

304. It is of course conceivable for a political regime to rest partly on mutuality and partly on coercive dominance. The trick in this conception is to construct separate tiers, limiting the bonds of mutuality only to acknowledged members of the polity and defining as "outsiders" those within the polity merely subject to coerced submission. This was the Founders' implicit, if somewhat ambivalent, way with slavery, a way made explicit and unambivalent by the Supreme Court in Dred Scott v. Sandford, 60 U.S. (19 How.) 393 (1857), and abandoned (at least for relations among all males) by the Civil War Amendments. Even if American society were to maintain this two-tiered regime, the acknowledged members must base their relations on mutual agreement or admit (as in fact occurred between white Northerners and Southerners in the Civil War) that the norms of the original constitutional enterprise no longer effectively govern their relations.

305. See Burt, What Was Wrong With Dred Scott, What's Right About Brown, 42 WaSH. \& LEE L. Rev. 1 (1985). 
majority has now done. Justices Brennan and Marshall committed an equivalent error in their premature abandonment of any effort to vindicate the values of fairness and rationality in the administration of capital punishment. They may have been correct that the death penalty ultimately would resist all such efforts; they may have been astute enough to discern this reality without actually attempting any such ameliorative enterprise. They did not err, as the majority Justices erred, in embracing the proposition that Order must prevail over the claims of Justice. Their error was in disregarding the process of social deliberation by which the reconciliation of Justice and Order might be achieved.

Justices Brennan and Marshall were obliged not merely to state the reasons that led them to their abolitionist conclusions. They, like all judges, were obliged to engage in a visible process of reasoning, a process that itself serves as a model for the kind of social discourse that painstakingly tries to avoid coercive imposition and to rest the exercise of authority on mutual persuasion. When judges properly honor this obligation, they avoid the sweeping, apodictic pronouncement; they speak as participants in an enterprise of mutual teaching and learning between Court and citizenry, a "vital national seminar."306 Justices Brennan and Marshall's abrupt embrace of abolitionism in Furman undermined this process as severely as did Justice Harlan's evasion of the enterprise in McGautha.

The clearest model for this judicial statecraft is provided by the Court's lengthy, increasingly relentless engagement in probing and challenging the regime of race segregation. The Court was heedless in its initial failure to insist on guaranteed equality in "separate but equal" facilities ${ }^{307}$ and then, after demanding this guarantee, was excessively dilatory in pressing for its implementation. ${ }^{308}$ But once the Court had seriously engaged this enterprise, it progressively estab(1952)

306. Rostow, The Democratic Character of Judicial Review, 66 HARV. L. REV. 193, 205

307. This was one of the flaws in Plessy v. Ferguson, 163 U.S. 537 (1896). Though the state statute at issue mandated "equal but separate accommodations," 163 U.S. at 540, the Court gave no special significance to this mandate but simply ruled that separate accommodations were not inherently unequal under the fourteenth amendment. Almost a generation passed before the Court held that racially segregated facilities were constitutionally required to be "equal" though "separate." McCabe v. Atchison, T. \& S.F. Ry., 235 U.S. 151, 160 (1914). See also Schmidt, Principle and Prejudice: The Supreme Court and Race in the Progressive Era, Part I: The Heyday of Jim Crow, 82 ColuM. L. REV. 444, 468-69, $485-94$ (1982).

308. The Court briefly flirted with this endeavor in Buchanan v. Warley, 245 U.S. 60,79 (1917), striking down a racially restrictive zoning ordinance because of its unequal effects, and again in its attention to the white primary practices, beginning with Nixon v. Herndon, 273 U.S. 536 (1927), and faltering in Grovey v. Townsend, 295 U.S. 45 (1935). But judicial engagement in attempting to give practical force to the promise of equality was not apparent until the graduate school education cases beginning with Missouri ex rel. Gaines v. Canada, 305 U.S. 337 (1938). 
lished an adequate predicate to demonstrate that the equality guarantee could not succeed because separate was "inherently unequal." 309 The Court then proceeded in the same visibly extended, incremental way ${ }^{310}$ to epitomize and to guide the social deliberative process by which a remedy, an alternative social arrangement for race relations, might be found that was consistent with more widely shared (and ultimately mutually agreed) norms of Justice. ${ }^{311}$ Many of the Justices who served on the Court during this extended period may have believed that they knew, from the outset of their engagement with the race segregation issue, the ultimately just and proper result. Whatever may have led these Justices to refrain from earlier imposition of their conception of this result, their restraint can be understood and justified as an expression of the proper judicial role in the realization of constitutional values.

This model of judicial conduct might have guided the Court during the past twenty years in its death penalty jurisprudence. Its decision in Witherspoon pointed the way; Justice Brennan's dissent in McGautha offered the particularized focus for subsequent development. But the Justices quickly turned away from serious engagement with this incremental, deliberative process - each intent instead on conclusively establishing either the validity or invalidity of the death penalty.

In the two years following Furman, the Court also decided Roe $v$. Wade ${ }^{312}$ and the Nixon Tapes case. ${ }^{313}$ In all three of these cases, the Justices grabbed hold of seemingly disruptive, hotly debated social issues and attempted to impose a conclusive resolution by forceful authoritative assertions. The debates on these issues in Congress and state legislatures appeared at the time to reflect and to reinforce more pervasive doubts about the legitimacy of our governmental institutions. These doubts were fueled by the prior decade's convulsive experience of political assassinations, race riots, and an Asian war whose brutality escalated as its intelligibility declined. Because the Justices saw themselves as the special guardians of legitimacy in American society, it is not surprising that they should also see a special curative mission for themselves arising from these convulsive challenges to legitimacy.

309. Brown v. Board of Educ., 347 U.S. 483, 495 (1954).

310. See Brown v. Board of Educ., 349 U.S. 294 (1955) (Brown II).

311. See Burt, supra note 96, at 485-86; see generally Gewirtz, Remedies and Resistance, 92 YALE L.J. 585 (1983).

312. 410 U.S. 113 (1973).

313. 418 U.S. 683 (1974). 
Some constitutional theorists have argued that the Justices cannot properly have such a guardianship role in our society. ${ }^{314}$ I believe that the historically sanctioned role of the Court as the "Guardian of the Constitution" 115 does indeed justify a conception of the Court as the special custodian of our institutional legitimacy. ${ }^{316}$ The central question is not whether the role exists but how it can be implemented properly. I believe that legitimacy cannot adequately or properly be purchased by authoritative fiat but can only be earned, in practice and in principle, by unrelenting attempts among all grievants to achieve sufficient understanding and accommodation to yield mutual tolerance, if not deeper bonds of loyalty and support.

Judges can and should play a facilitative role in the workings of these deliberative processes - not simply to assure that the political branches are structurally open to these processes, ${ }^{317}$ but to assure that these processes actually occur. This requires diplomatically adroit involvement by judges in publicly debated issues; but judges must participate in the debate, not end it by self-righteous proclamation. Judges should not fear or suppress controversy and its open expression; they should cultivate it, while attempting to guide and focus it toward a mutually respectful and widely inclusive public resolution. The specific controversies vary from one generation to the next, but the underlying questions posed are always the same (and should guide judges' choices for involvement accordingly). The crucial issues are those that raise serious doubts about the disputants' willingness or capacity for mutual tolerance and accommodation - doubts which necessarily challenge the existence of the shared allegiances essential to legitimate social institutions. ${ }^{318}$

By these lights, capital punishment was ripe for judicial involvement when the Court first seriously addressed it in the late sixties. But equally by these lights, virtually none of the Justices has properly approached the issue: not the abolitionist Justices who were prepared almost from the outset to end the dispute, nor those Justices who were

314. Judge Learned Hand's pithy objection has been frequently reiterated to make this point: "For myself, it would be most irksome to be ruled by a bevy of Platonic Guardians, even if I knew how to choose them, which I assuredly do not." L. HAND, THE BILL OF RIGHTS 73 (1958).

315. The Federalist No. 78, at 524 (A. Hamilton) (P. Ford ed. 1898).

316. See Burt, supra note 96 , at $465-67,486-88$.

317. This is the limitation on the function of judicial review that John Ely essentially would impose. See generally J. Ely, Democracy AND Distrust: A Theory OF Judicial Review (1980).

318. See generally M. WALZER, Obligations: ESSAys ON DisobedienCE, WAR AND CiTIZENSHIP (1970). 
quick to conclude that the only proper role was to legitimize embattled authority by dismissing any serious challenge to capital punishment.

\section{"AFTER THE FIRST DEATH, THERE IS NO OTHER"319}

The current phase in the Court's death penalty jurisprudence may not be its last. Continued litigative pressure from growing numbers of death penalties imposed (and implemented) may ultimately erode the majority Justices' resolve to turn a collective blind eye toward the enterprise. The district judge in Lockhart, Chief Judge Eisele, suggested at the end of the inquiry conducted in his courtroom into one aspect of the capital punishment system, "Tension develops because the verbal rationalizations and justifications for those practices are at odds with our intuitive feelings and judgments as to the real truth of the matter." 320 This kind of tension, kept visible, progressively worked on the Court and in the country to unravel the race segregation regime. ${ }^{321}$

The events surrounding the execution of John Spenkelink suggest why this tension will persist notwithstanding the Court's current suppressive efforts. Spenkelink was executed by the state of Florida on May 25, 1979, thus ending the national moratorium in place since 1967. Spenkelink had been convicted in 1973 of murdering a traveling companion who, he alleged, had previously stolen money from him and had forced him to engage in homosexual acts. Spenkelink claimed that the two were struggling together when he shot in self-defense, but the state contended that the other man had been sleeping when Spenkelink shot him. ${ }^{322}$ His conviction was affirmed on direct appeal two years later; ${ }^{323}$ by May 1979 his subsequent petitions for collateral relief had been denied twice by the Florida Supreme Court ${ }^{324}$ and twice by the Fifth Circuit, with certiorari denied by the Supreme

319. D. Thomas, A Refusal to Mourn the Death, by Fire, of a Child in London, in COLlected Poems 101 (1956).

320. Grigsby v. Mabry, 569 F. Supp. 1273, 1322 (E.D. Ark. 1983), affd., 758 F.2d 226 (8th Cir. 1985) (en banc), revd. sub nom. Lockhart v. McCree, 106 S. Ct. 1758 (1986).

321. See generally G. Myrdal, AN AMERICAN Dilemma lxix-lxxvi, 997-1015 (1944).

322. Spinkellink v. State, 313 So. 2d 666, 668 (Fla. 1975), cert. denied, 426 U.S. 911 (1976). Spenkelink's name was repeatedly and variously misspelled in the case reports, see Spinkellink v. Wainwright, 578 F.2d 582, 582 n.1 (5th Cir. 1978), a distinction he shares with other notable cases in American constitutional jurisprudence, see Danzig, Justice Frankfurter's Opinions in the Flag Salute Cases: Blending Logic and Psychologic in Constitutional Decisionmaking, 36 STAN. L. REv. 675, 678-79 (1984) (regarding Minersville School Dist. v. Gobitis); Burt, supra note 305, at 5 (regarding Dred Scott v. Sandford).

323. Spenkelink v. State, 350 So. 2 d 85 (Fla.), cert. denied, 434 U.S. 960 (1977).

324. Spenkelink v. State, 350 So. 2d 85 (Fla.), cert. denied, 434 U.S. 960 (1977); Spenkelink v. State, 372 So. $2 d 65$ (Fla. 1979). 
Court. ${ }^{325}$ Notwithstanding these prior defeats, attorneys on his behalf predictably filed new motions in both state and federal courts as his scheduled execution loomed. Less predictably perhaps - in light of their repeated prior review - these courts showed considerable strain in rejecting Spenkelink's final appeals.

This strain, and the consequent obstacles toward devising an orderly, regularized regime for administering the death penalty, are shown in an account by Arthur England, Chief Justice of the Florida Supreme Court in 1979. England had twice previously concurred in his court's denial of relief to Spenkelink. ${ }^{326}$ This is his extended account of his final concurrence, told at a Yale Law School seminar in 1985:

I got a call at two o'clock in the morning from some attorneys who wanted to make an argument that [Spenkelink's] . . . execution should be stayed. I did not deny them that right. I was foggy, it was late at night, but I said, "Fine, be at my house at seven o'clock." I hung up and I realized I'd said "be at my house." What am I doing holding court in my house? But I had said it.

I called the other members of the court. I called my research aide and I said, "Mike, do what's necessary to have coffee and pencils. We're having court at seven a.m." And at seven a.m. that morning - he was scheduled to be executed, I believe, at ten o'clock - my front yard was filled with cars, the Attorney General of the state, assistants, . . . some lawyers who were arguing . . . [for Spenkelink]. One of the first questions that came to mind was, "Who are these lawyers? By what authority do they represent him? There've been lawyers in this case for years." But we didn't want to waste time with that. We just wanted to hear what they had to say.

In my living room we heard arguments from both sides. We had no place to adjourn in my house; we don't have a back room. So we adjourned there; they went out in the yard. And we sat and deliberated on what points they had raised. We concluded they were not a basis for a stay and called them back in and told them that was that.

The phone rang. The Governor had been advised, of course, by the Attorney General that there was this hearing and needed to know to tell the warden what to do at Raiford State Prison or not. We only had one telephone line in the house - three extensions but only one line. My daughters had their phone in their room. The Governor wanted to be sure our line was open. And the Attorney General reported to him what had happened.

We immediately got another call from some people in New Orleans who wanted to argue another ground for a stay of execution. I didn't

325. Spinkellink v. Wainwright, 578 F.2d 582 (5th Cir. 1978), cert. denied, 440 U.S. 976 (1979); Spinkellink v. Wainwright, 596 F.2d 637 (5th Cir. 1979).

326. Spenkelink v. State, 350 So. 2d 85, 86 (Fla. 1977) (England, C.J., concurring); Spenkelink v. Wainwright, 372 So. 2d 927, 927 (Fla. 1979) (England, C.J., concurring). 
want to deny them the right to do it. I was scared to death to deny them the right to do it. I didn't know what they wanted to say. Maybe it would be the basis upon which we would stay the execution.

How do you do that - seven Justices in the living room and three phones? Well, you put three of them on the phone and listen to the argument. The Attorney General can't hear what they're saying and we had to come back and translate what the motions were and get their reactions to the telephone motions and the grounds that were being considered. We adjourned them again to the front yard.

... [Then] we went out to get them. ... The Governor was frantic trying to get through to us while we were on this call. Everything was chaotic. Finally we made our last decision, I think, thirty, thirty-five minutes before the scheduled execution. The Attorney General called the Governor and confirmed that was the result.

This was to be on television. There was a television set in our living room. I don't think anybody wanted to watch it. But we didn't know what to do. Nobody wanted to leave: the attorneys for Spenkelink, the Attorney General and all his assistants. Everybody was immobilized by this process.

So we watched what happened on television. We couldn't see the execution. What we saw was the outside of the prison and that sort of stuff. After it occurred, there must have been silence - just - I don't know what it was. It was an immobile silence for five or ten minutes. Nobody wanted to go anywhere, to do anything. Nobody had any idea what they were to do next. Nobody on the court wanted to go in the office and decide cases.

Fifteen, twenty minutes later we got a call from the Attorney General's office, that his wife and children had been threatened, that they were being protected, that they had been spirited away, and that it was not advisable for him to come to the office. The same with some of his assistants.

We didn't get such threats. But it was emotionally devastating to be a part of this process. And I can't even capture it in words. I can't even give you a sense of what it was like. We walked around like zombies for a day - I'm sure all of us did. We were pinned down - even people who were advocating capital punishment repeatedly in the courts and had been doing so for five, ten years, and who believe it's in the public interest. The toll-taking is very, very heavy.

It occurs to me that I may be wrong on some of these steps. It's just dawned on me. I may have them out of sequence or I may not have them accurately - because I was living them at the time and my recollection may be off. It would be interesting . . . to see if [others] remember two hearings. I'm sure it was in the house. After that I really don't know. It would be interesting to find out. ${ }^{327}$

Chief Justice England thus testified to the personal strain involved in acting as a judge in this case. His account recalls Justice Black-

327. Remarks of Chief Justice Arthur England, Yale Law School Seminar (Apr. 18, 1985) (transcript on file with the Michigan Law Review). 
mun's separate dissent in Furman: "[A]n excruciating agony of the spirit ... with all its aspects of physical distress and fear and of moral judgment exercised by finite minds." 328 Arthur England took refuge from his emotional devastation, he told our seminar, not only in his general conception of his judicial role but in his specific obligation not equally applicable to Justice Blackmun - of obedience to the hierarchically superior authority of the United States Supreme Court. But the strain was evident nonetheless.

This same strain had observable systemic consequences. The small irregularity noted by Chief Justice England - that somehow the last state court proceedings involving John Spenkelink were conducted in his home - had much more extensive expression in the final federal court proceedings in the case. As England's account mirrors Justice Blackmun's observations in Furman regarding the personal impact of the death penalty on judges, these last federal proceedings in Spenkelink reflect the systemic disorder that the cacophony of Furman revealed in the Supreme Court.

The last federal proceedings were pursued by attorneys acting separately from those in the state court at the same time. This extraordinary infusion of lawyers came, of course, because of Spenkelink's notoriety as the case that might end the twelve-year moratorium. The hectic, last-minute character of the infusion came specifically because it had not been clear, until little more than a week before his scheduled execution, that Spenkelink rather than some other prisoner in Florida (or in some other state) was first in line to break the moratorium. Numerous attorneys not previously involved in his case suddenly were moved to scrutinize it intensively.

One of these newly involved attorneys was Ramsey Clark, a former Attorney General of the United States. Clark had flown to Florida on May 22 not to represent Spenkelink but to participate in a protest vigil - as he put it, "to bear witness" 329 - at Spenkelink's anticipated execution. When Clark arrived in Jacksonville, however, he received an emergency call from an American Civil Liberties Union attorney in Atlanta who had pored through Spenkelink's records for the first time and had found grounds for appeal in previously unnoticed aspects of Spenkelink's trial. Clark subsequently wrote this magazine account of what transpired:

She began a litany of allegations familiar to all who have followed capital trials in the United States these last years. John Spenkelink's trial attorneys were court-appointed. They lacked sufficient resources to

328. Furman, 408 U.S. at 405 (Blackmun, J., dissenting).

329. Clark, Spenkelink's Last Appeal, THE NATION, Oct. 27, 1979, at 385. 
prepare and conduct the defense... . [Clark then listed a lengthy series of strategic errors that experienced counsel would never have committed: failure to challenge the composition of grand and petit juries, failure to request severance from trial with a co-defendant later acquitted, errors in arguments to the jury and the like.]

Then came what was for me the clincher. Spenkelink's father was a paratrooper in World War II. ... The war weighed heavily on him. Life wasn't easy thereafter. To his son he was a hero.

One day, when John was 11 , his father went into the garage, attached a hose to the car exhaust, started the motor, put the hose in his mouth and asphyxiated himself. John found his father dead on the garage floor with the hose in his mouth. The troubled youngster began a career of minor crime. Prison psychiatrists examining him over the years wrote that his criminal behavior was in large part due to the suicide of his father and that he was amenable to treatment. Incredibly, when the sentencing phase of the case was tried, these facts were not presented to mitigate the punishment. A jury would not give a death penalty in the face of such evidence. John Spenkelink was a second-generation casualty of World War II. ${ }^{330}$

On this basis, Clark concluded that Spenkelink had been denied his constitutional right to effective assistance of counsel. He agreed to fly immediately to Atlanta to present a new petition with this allegation to a federal judge there. There were, of course, federal, and even state, judges closer at hand in Florida. But Clark, as the phrase goes, went shopping for the most favorably inclined forum; his choice was Elbert Tuttle, a federal court of appeals judge who not only sat in Georgia but who had long since retired from active service. Clark knew and esteemed Tuttle from the old civil rights days of the fifties and sixties.

At eleven p.m. on May 22, Clark presented himself at Tuttle's home with a petition to stay Spenkelink's execution:

Mrs. Tuttle answered the door, and graciously led us to her living room. As we settled down with Judge Tuttle, she retired. I had not seen him in a decade. Now in his early 80s, Judge Tuttle was as erect, dignified, alert and interested as ever. He knew of course why we were there. $\mathrm{He}$ stated at the outset that he was pleased to meet with us, that he would read our petition and hear our plea. But he cautioned us that he had not granted a writ of habeas corpus since assuming senior status a dozen years earlier and did not see how he could do so now. Then he asked why we had come from Florida to bring a Florida case to him. ...

I gave him a hard, straight answer. This case had been in the courts for six years. The Federal district judges in Florida had reviewed it at length time and time again. It had been rejected on other grounds just the day before by the District Court in Florida. The Legal Defense Fund

330. Id. at $400-01$. 
had made prodigious efforts at the District, Appellate and Supreme Court levels.

Now we were eight hours away from an execution and a new and difficult question, never raised in the case, and one courts and lawyers alike abhor, was raised. Did Spenkelink's court-appointed Florida lawyers represent him effectively? There was little chance that judges with six years' involvement behind them would consider this new issue. And then it would be too late to go elsewhere. We needed a very courageous, very independent, open-minded and fair judge. That is why we chose Judge Tuttle. That is what I told him. ${ }^{331}$

Clark's answer satisfied Tuttle. He then heard the substantive allegations on which Clark based his claim and immediately stated that he would grant the stay to permit an evidentiary hearing on the allegations. The statute on which Tuttle grounded his jurisdiction provided that an individual appellate judge could either assign this hearing to an appropriate district judge or conduct it himself. ${ }^{332}$

Tuttle's action was, to use a somewhat neutral word, unconventional. The rationale offered by Clark for his blatant forum-shopping appeared to be nothing more than a claim that other judges who were familiar with the case and had heard other aspects of it were unlikely to grant his petition. But the immediate context of the case - the imminence of Spenkelink's death - gave a different shading to this claim. These other judges, Clark implied, would be closed-minded because they would expect desperate stratagems to save Spenkelink and even because they might prefer to turn away from the stress of the imminent execution and the seeming responsibility for it repeatedly forced on them by defense attorneys. If these extraneous factors influenced the Florida federal or state judges, they would not attend to the merits of Clark's argument. The unarticulated premise on which Clark invited Tuttle to act was that other judges would act injudiciously. But if Tuttle believed that his colleagues were prone to bias because of the imminent execution, he must somehow also conclude that his judgment was not inappropriately swayed by this same fact, a difficult question to resolve, especially without the luxury of time and the honing effects of adversarial argument for assistance. So Judge Tuttle stopped the execution.

Immediately the next morning, the Florida attorney general flew to Washington to present a petition to the Supreme Court to vacate Tuttle's order. The Court declined the following day, May 24, with Justice Rehnquist noting his dissent. ${ }^{333}$ In a subsequently filed opinion,

331. Id. at 401-02.

332. 28 U.S.C. $\$ 2254$ (1982).

333. Spenkelink v. Wainwright, 442 U.S. 901 (1979). 
Rehnquist was harsh to the point of caricature in his criticism of any attorney who would seek this last-minute stay:

It strains credulity to suppose that six years and countless courthouses after his trial, respondent suddenly determined that his trial attorney had been ineffective. Either he does not believe the claim himself or he had held the claim in reserve, an insurance policy of sorts, to spring on the federal judge of his choice if all else fails. This Court has disapproved of such tactics before ... [as] "needless piecemeal litigation ... whose only purpose is to vex, harass, or delay." 334

For the judge prepared to grant such stay, Rehnquist's criticism was more restrained but equally pointed:

[B]ecause the imposition of the death penalty is irreversible, I respectfully suggest that there may be a tendency on the part of individual judges or courts ... to create or assume [constitutional] ... doubts where in fact there are none.

... [T]here are several hundred federal judges in the United States who have authority to issues stays. ... As the new execution date approaches, new claims are conceived and, at the last minute, new stay applications are filed. Understandably, because no mortal can be totally satisfied that within the extremely short period of time allowed by such a late filing he has fully grasped the contentions of the parties and correctly resolved them, judges are inclined to grant such 11th-hour stay applications. Then, again, new execution dates must be set and the process begins anew. This now familiar pattern could in fact result in a situation where States are powerless to carry out a [constitutionally valid] death sentence. .... ${ }^{335}$

Rehnquist characterized the systemic implications both of Clark's conduct as an attorney and Tuttle's as a judge as "at odds with a government of law." 336

Rehnquist filed his opinion on May 25, the day after the Court had acted and the very day that Spenkelink was executed. The execution occurred because Judge Tuttle's stay was vacated by the swift action of a three-judge panel of the Eleventh Circuit, an action which itself strained the boundaries of governance under law. The jurisdiction of this panel to review Judge Tuttle's order was doubtful. The procedures it followed in exercising this review were haphazard and thus questionable. As if in response to Tuttle's (and Ramsey Clark's) disregard for the ordinary conventions against forum-shopping and their implicit disrespect toward the federal judges sitting in Florida, the panel itself was inattentive to the ordinary conventions governing judicial conduct.

334. 442 U.S. at 905-06 (quoting Sanders v. United States, 373 U.S. 1, 18 (1963)).

335. 442 U.S. at $902-03$.

336. 442 U.S. at 904. 
On May 23, the same day it asked the Supreme Court to vacate Judge Tuttle's stay, the state of Florida also sought the same result from the Fifth Circuit Court of Appeals. The state's motion was routinely assigned to a panel consisting of Judges James Coleman (based in Mississippi), Peter Fay (based in Florida), and Alvin Rubin (based in Louisiana). ${ }^{337}$ Late that afternoon, the state's written motion with supporting papers was delivered to the court clerk in New Orleans. A deputy clerk read the material by telephone to Judge Coleman that afternoon and to Judge Fay the next morning; a copy of the material was forwarded to Judge Rubin that same morning. The judges conferred among themselves by phone. Though the court rules did not require any oral argument regarding such motions, Coleman and Rubin agreed on May 24 to convene a conference telephone call with the parties. Judge Fay indicated that he could not be available for the call but asked the other judges to tell him what occurred. The conference call was accordingly convened at seven p.m. on May 24.

This is Ramsey Clark's account of it:

The telephone conference was a nightmare. We were told at the beginning not to record what was said. The court did not have our papers. We had not seen the State's papers. Some factual statements in the State's papers were in error, but we could not know this until we saw them some days later. We were asked whether we had gone to Spenkelink and urged him to attack his trial lawyers, to which we replied, if so, discipline us, do not kill him without determining his rights. There was loose, unstudied, uninformed discussion about whether Judge Tuttle had jurisdiction, whether he entered a final order, whether the Court of Appeals had power to review his order.

It soon became clear that the bizarre late-night argument over longdistance phone among lawyers and judges who had not seen the papers in the case nor been briefed on the issues was worse than meaningless; it was dangerous. I complained and Judge Coleman replied that he was not legally required to give us the opportunity to discuss the matter over the telephone. We asked for time to file affidavits and a response to the State's motion. The merits of our petition for a writ of habeas corpus had been barely discussed. A representative of the Attorney General's office, ... [the other ACLU attorneys,] and I made some emotional conclusory statements and the call was over shortly after 8 p.m..$^{338}$

Three hours later the panel entered an order vacating Judge Tuttle's stay, indicating that its "reasons will hereafter be stated in a formal opinion" and noting that Judge Rubin "reserves the right to

337. See Report of John R. Brown, United States Circuit Judge, Fifth Circuit, Alleged Complaints as to Action of James P. Coleman, Now Chief Judge, and Peter T. Fay, Alvin B. Rubin, Circuit Judges, 12-13 (July 16, 1980) (unpublished memorandum) (on file with the Michigan Law Review) [hereinafter Brown Report].

338. Clark, supra note 329 , at 403. 
dissent for reasons to be assigned." 339 No such opinions ever were issued. The panel postponed the effectiveness of its order until ninethirty the next morning, May 25. Clark drove through the night from New York to Washington where, at seven a.m., he presented a petition to the Supreme Court to overturn the panel's decision and reinstate Judge Tuttle's stay. At ten a.m., Clark was notified that the Court had denied his petition, with Justices Brennan and Marshall noting their dissents. ${ }^{340}$ Within the hour, Spenkelink was dead.

Questions about the propriety of the panel's action, however, were not finished. Clark's magazine account provoked a letter to the Chairman of the House Judiciary Committee from a law school dean (and former Legal Defense Fund attorney). ${ }^{341}$ This in turn brought a formal letter of complaint from a House Judiciary subcommittee chairman to the Fifth Circuit invoking its new rules for complaints against judges. ${ }^{342}$ In July 1980, the senior judge to whom the complaint was referred, John Brown, issued a report dismissing all the questions raised - whether the panel should have conducted full-scale oral argument, whether Judge Fay should have participated in the panel decision even though he had not taken part in the conference phone call with the parties, whether the panel should have granted Clark's request for time to review and respond to the state's papers, and whether the panel should ultimately have issued an opinion. The basis for Brown's dismissal was that all these matters were "judicial decisions" that could not be questioned. ${ }^{343}$

In a narrow sense, Brown's dismissal might have signified only that the Fifth Circuit complaint rules were intended to address gross judicial misconduct such as bribe-taking, while the questions raised in the Spenkelink proceedings were cognizable only in an ordinary appeal to the Circuit Court en banc or to the Supreme Court. But Brown could not confine himself to this ground. He felt obliged to comment on the merits: "[B]ecause of the manner in which these charges have been disseminated I think the reputation of these Judges, indeed that of the Court itself, warrants a more detailed discussion. . .."344 Judge

339. Spinkellink v. Wainwright, No. 79-8215 (5th Cir. May 24, 1979) (order vacating stay of execution).

340. Clark, supra note 329, at 403-04.

341. Letter from Michael Meltsner, Dean, Northeastern University School of Law, to Rep. Peter W. Rodino, $J_{\Gamma}$., Chairman, U.S. House of Representatives Judiciary Committee (Nov. 20, 1979).

342. Letter from Rep. Robert W. Kastenmeier, Chairman, Subcommittee on Courts, Civil Liberties and the Administration of Justice, U.S. House of Representatives Judiciary Committee, to Gilbert F. Ganucheau, Clerk of the Fifth Circuit (Jan. 16, 1980).

343. Brown Report, supra note 337, at 2, 4, 23, 29.

344. Id. at 5 . 
Brown's extended defense of the panel's action anticipated the defensive strategy that the Supreme Court eventually adopted wholesale in its current phase: to suppress all doubts regarding the administration of the death penalty.

Brown took two interrelated tacks. First, he claimed that the panel's actions were simply the ordinary everyday conduct of all judges. Only half the decisions rendered by the Fifth Circuit since 1968, he said, were preceded by oral argument; judges regularly decide "whether to hold oral submission, and if so for what length of time and under what circumstances." 345 Similarly, he said, judges "deal almost daily" with the question of whether to issue opinions to accompany their decisions; ${ }^{346}$ a circuit rule explicitly permitting discretionary issuance of orders without opinions had been employed in onefourth of the court's decisions since 1970.347 Brown's basic defense was thus that the panel had treated Spenkelink no differently than any other case, and the very ordinariness of its disposition of these issues was justification for that disposition.

The problem with this defense is that Spenkelink was not an ordinary case. The imminence of death was an extraordinary element. Brown might respond, as the Supreme Court ultimately answered, "Our court chooses to regard it as no different from other cases, at least for the specific practices challenged." This would be a logical rejoinder. There was, however, at least one large difficulty with it. That difficulty lies in the very actions of the panel in Spenkelink that Brown tried to characterize and justify as ordinary judicial conduct. In fact, the panel did not engage in ordinary conduct; it was moved by the imminence of Spenkelink's execution to extraordinary actions. Of course, appeals court panels regularly dispense with oral arguments, as Brown indicated; but how commonly do the panels conduct a hybrid oral argument by long-distance conference telephone calls? Of course, courts frequently issue decisions without supporting opinions; but how often does a court explicitly promise that an opinion will follow and then, without explanation, renege on the promise? Although the judges may have wanted to treat Spenkelink as an ordinary proceeding, they could not bring themselves to do so. The imminence of Spenkelink's death nagged at the judges; it pulled them from their well-practiced routines. Once they implicitly had acknowledged, by their unconventional actions, that the proceeding was not ordinary,

345. Id. at 22.

346. Id. at 25.

347. Id. at 26 (citing 5TH CIR. R. 21). 
they themselves had established the basis for demanding a more cautious, more painstaking deliberative process than is customary.

In his effort to domesticate death cases, to make them practicably manageable, Judge Brown refused to acknowledge that the panel's actions themselves betrayed this domesticating effort. Brown's pretense about the ordinariness of the panel's conduct nonetheless had a plausible purpose insofar as he looked toward future death penalty appeals in their last, desperate moments. Such cases become manageable only if they can be regularized, treated according to the norms of ordinary judicial business. If, however, it is hard to keep these cases compartmentalized, then more is required than simply announcing to judges that they are henceforth permitted to treat these cases in the ordinary mode. Judge Brown did not acknowledge the difficulty of such compartmentalization, as the Supreme Court later did, but Brown took the same approach at this point that the Court would later adopt. Brown not only invited judges to give no extraordinary attention to death cases in the future, but he also closed off the possibility that anyone could question judicial conduct in these cases. This was Brown's second major tack in defending the Spenkelink panel.

Brown pursued this goal by two means. First, he posited a substantive standard of such extreme deference as virtually to preclude the possibility of external review. Brown accomplished this with a kind of double entendre that he gave the phrase "judicial decision." At first he seemed to use this phrase with some normative content: the panel's actions in withholding oral argument and the like were ordinary "judicial decisions" - justifiable, that is, with reference to the ordinary conduct of judges. ${ }^{348}$ But by the end of his report, the phrase had attained a more conclusory meaning:

The panel here determined that further oral presentation was not called for. By its very nature that was an important but judicial decision made in every case that comes before us and assuredly made in these proceedings. Whether I, as a panel member, or other panels would or would not have decided differently is not a proper subject for inquiry in assaying these complaints. ${ }^{349}$

By this light, anything done by a judge is a "judicial decision" inherently justified as such; it is an irrefutable ipse dixit.

Second, Brown employed procedures to move toward the goal of closing off the likelihood of external scrutiny. He took this step with the concurrence of his colleagues on the Fifth Circuit. At the outset of his report, Brown announced that the Judicial Council of the Fifth

348. Id. at 20-22.

349. Id. at 23. 
Circuit had amended its rules governing complaints against judges, following the filing of the complaint by the chairman of a House Judiciary subcommittee. Henceforth, complaints would be accepted only from "a party or counsel" and must be "verified by the affidavits of persons having personal knowledge of the alleged conduct." 350 Members of Congress and law school deans no longer would have standing to complain about the administration of the death penalty in the Fifth Circuit. In itself a conventional limitation of access to federal courts, this amendment nonetheless was symptomatic of the Supreme Court's more thoroughgoing effort to restrict the range of questions and of people permitted to challenge the capital punishment system.

Spenkelink was, of course, extraordinary because of its immediate significance as the case that ended the twelve-year moratorium on executions. But the personal distress and systemic chaos prompted by this one case did not expire with it. Spenkelink revealed forces that work against any orderly administration of the death penalty. The extremity of the measures that the Supreme Court soon thereafter embraced to reinforce the death penalty testified to the magnitude of those forces. John Spenkelink's execution has not ended the influence he and those who have followed him exert below the surface order imposed by the Court.

Of those Justices currently on the Court, two show particular signs of stress. Heretofore, Justices Stevens and Blackmun both have insisted that state death penalty statutes could be applied constitutionally. Stevens has been most consistent in sustaining inquiry into whether and by what specific means a fair and rational capital punishment regime could be constructed. ${ }^{351}$ (Stevens came relatively late to the enterprise, beginning his tenure with Gregg, and thus was not burdened with having participated in the Court's erratic course from Witherspoon to McGautha to Furman.) In recent years, however, increasing distance has appeared between Justice Stevens' conception of the elements necessary to ensure justice in the administration of the death penalty and the requirements that the current Court majority is prepared to impose. Stevens dissented in $\mathrm{McCleskey} \mathrm{regarding} \mathrm{racial}$ bias in capital sentencing ${ }^{352}$ and in Lockhart regarding the convictionproneness of capital juries. ${ }^{353} \mathrm{He}$ also dissociated himself from the Court majority's evisceration of the Witherspoon jury exclusion

350. Id. at 3 n. 3 (emphasis removed).

351. See Note, Death and a Rational Justice: A Conversation on the Capital Jurisprudence of Justice John Paul Stevens, 96 YALE L.J. 521 (1987) (authored by Scott Burris).

352. 107 S. Ct. at 1805 (Stevens, J., dissenting).

353. $106 \mathrm{~S}$. Ct. at 1770 (Marshall, J., joined by Brennan and Stevens, JJ., dissenting). 
rules, ${ }^{354}$ from its approval of expedited collateral review in federal appeals, ${ }^{355}$ and (though less clearly) from its diminished demands for state appellate proportionality reviews. ${ }^{356}$ Accordingly, even if Stevens remains convinced that a just regime of capital punishment is possible in principle, he must now decide whether the death penalty as approved by the Court majority is so far from his understanding of the ideal that he must join the abolitionist Justices. ${ }^{357}$

Justice Blackmun recently seems to have revealed some similar bases for doubt. In three death penalty cases, all decided on the same day in 1983, ${ }^{358}$ Justice Blackmun suddenly appeared in an unusual role. During the preceding decade, after his declaration in Furman of conflict between his personal beliefs and his judicial obligations, ${ }^{359}$ Blackmun remained virtually silent in capital cases though he occasionally voted to overturn death sentences. ${ }^{360}$ In the three 1983 cases that marked the beginning of the Court's current phase of closed inquiry, however, Blackmun seemed almost to explode in rhetorical force. In one case: "This kind of appellate review [by the Supreme Court] compounds the original unfairness of the ... [state court's action], and thereby does the rule of law disservice."361 In the second case: "[T]his is too much for me. . . The danger of an unreliable death sentence . . . cannot be brushed aside [as the Court has done] ...."362 In the third case: "The errors and missteps - intentional or otherwise - [overlooked by the Court] come close to making a mockery of the Florida statute and are too much for me to condone. . . .

354. See Wainwright v. Witt, 469 U.S. 412, 436-38 (1985) (Stevens, J., concurring). See also Darden v. Wainwright, 106 S. Ct. 2464, 2476 (1986) (Blackmun, J., joined by Brennan, Marshall, and Stevens, JJ., dissenting).

355. See Barefoot v. Estelle, 463 U.S. 880, 906 (1983) (Stevens, J., concurring).

356. See Pulley v. Harris, 465 U.S. 37, 54 (1984) (Stevens, J., concurring). See also his dissent to the majority's approval of exclusive judicial authority for capital sentencing in Spaziano v. Florida, 468 U.S. 447 (1984), and his dissents in Tison v. Arizona, 107 S. Ct. 1676 (1987) (permitting death sentence for co-felon who neither killed nor intended to kill victim), and California v. Brown, 107 S. Ct. 837 (1987) (approving jury instruction cautioning against mere sympathy for defendant).

357. For an acute account of the internal inconsistencies to which Stevens has come in his death penalty jurisprudence, see Note, supra note 351 .

358. Barefoot v. Estelle, 463 U.S. 880 (1983); Barclay v. Florida, 463 U.S. 939 (1983); California v. Ramos, 463 U.S. 992 (1983).

359. 408 U.S. at 405-06 (Blackmun, J., dissenting).

360. He joined silently, for example, in Coker v. Georgia, 433 U.S. 584 (1977) (excluding rape as capital offense); Godfrey v. Georgia, 446 U.S. 420 (1980) (state supreme court inconsistently applied its own standards); and Enmund v. Florida, 458 U.S. 782 (1982) (excluding vicarious liability for participation in felony-murder as capital offense). He spoke in Lockett v. Ohio, 438 U.S. 586, 613 (1978), only to explain that his reasons for invalidating the statutory limitations on mitigating factors were narrower than the plurality's justification.

361. California v. Ramos, 463 U.S. 992, 1029 (1983) (Blackmun, J., dissenting).

362. Barefoot v. Estelle, 463 U.S. 880, 916, 925 (1983) (Blackmun, J., dissenting). 
The end does not justify the means even in what may be deemed to be a 'deserving' capital punishment situation." 363

Blackmun's discontent has become even more prominent during this past Term. Blackmun began his dissent in McCleskey, "I am disappointed with the Court's action ...."364 This same expression of an almost elegiac sadness appeared in Blackmun's dissent from the Court's ruling that a capital sentencing jury can be instructed not to be swayed by "mere sentiment" or "sympathy" for the defendant. Blackmun stated,

Long ago, when, in dissent [in Furman], I expressed my fear of [mandatory death penalty statutes] ..., I observed that such legislation ... "[would] eliminat[e] the element of mercy. ..." [W]e adhere so strongly to our belief... [in the relevance] of compassion for the individual because ... we see in the sentencer's expression of mercy a distinctive feature of our society that we deeply value. ${ }^{365}$

This newly vocal posture for Blackmun does not mean that he has converted to judicial abolitionism. ${ }^{366}$ It means only that the escalated intensity of the Court's new phase in rejecting challenges to the death penalty has entailed some consequences that are, as Blackmun put it, "too much" for him. The new phase did not silence his doubts; it has seemed to magnify them. ${ }^{367}$

It is difficult to predict what lessons Justices Stevens and Blackmun ultimately will draw from their long involvement in death penalty litigation. It is easier to discern the dispositions of other Justices, but equally difficult to draw from this generation-long litigative experience any clear lesson about the merits of the abolitionist claim that the norms of Justice are antithetical to the maintenance of the death penalty. A current Supreme Court majority clearly has resolved to abandon the enterprise of scrutinizing the administration of the death penalty. The disorder, the cacophony, in the Court's own prior delib-

363. Barclay v. Florida, 463 U.S. 939, 991 (1983) (Blackmun, J., dissenting).

364. 107 S. Ct. at 1794 (Blackmun, J., dissenting).

365. California v. Brown, 107 S. Ct. 837, 850 (1987) (Blackmun, J., dissenting) (quoting Furman, 408 U.S. at 413 (Blackmun, J., dissenting)).

366. Blackmun wrote the opinion for the Court in Spaziano v. Florida, 468 U.S. 447 (1984), upholding a statute vesting exclusive judicial authority for capital sentencing with a merely advisory role for juries; and though he did not join the Court's opinion in Lockhart, rejecting claims of conviction-proneness for death-qualified juries, he nonetheless concurred "in the result" without any explanation, $106 \mathrm{~S}$. Ct. at 1770.

367. See Darden v. Wainwright, 106 S. Ct. 2464, 2482-84 (1986) (Blackmun, J., dissenting) (criticizing the majority's narrow application of jury exclusion rules drawn from Witt, 469 U.S. 412 (1985), even though Blackmun had joined with the Court to rework Witherspoon). In his Darden dissent, Blackmun also noted with some asperity "this Court's impatience with the progress of Darden's constitutional challenges to his conviction and death sentence," $106 \mathrm{~S}$. Ct. at 2484, and criticized Chief Justice Burger for publicly dissenting from the grant of certiorari because of the number of prior adjudications Darden had obtained, $106 \mathrm{~S}$. Ct. at 2484-85 n.9. 
erative process, however, makes it difficult to see whether this abandonment comes because the rationalizing enterprise has failed or because it was never seriously attempted.

The disorder in the Court's processes testifies to a persistent tension within the Court regarding capital punishment. It is not clear whether this tension will remain a vital disturbing force and, if so, whether or when it will reach past those directly and unavoidably participating in or examining the administration of the death penalty. Those on the front lines who sense this tension may allay it by conceiving of themselves as mere obedient instruments of a higher authority (the Supreme Court, the People), while those hierarchical superiors deny their responsibility by refusing to scrutinize acts done in their name. The result is a shell game of moral accountability. In the long run, these interlocking deceptions probably cannot be sustained. But, to adapt John Maynard Keynes' observation, in the long run, many will have died.

Only one clear lesson can be drawn from the Supreme Court's prolonged experience with capital punishment. The Justices have provided this lesson, though unwittingly, by embodying their conception of American society: In conflicts among implacably opposed adversaries, nothing is ever sensibly resolved or learned. 